\title{
Nano-Metal Oxide Based Supercapacitor via Electrochemical Deposition
}

\author{
Saima G Sayyed, ${ }^{1}$ Mahadeo A Mahadik, ${ }^{2}$ Arif V Shaikh, ${ }^{1}$ Jum Suk Jang ${ }^{2}$ and Habib M Pathan ${ }^{3}$
}

In this rapid growing world, the demand of alternate or non-conventional energy sources with high density and power has been tremendously increased. Supercapacitor is one of the promising energy storage devices which possess high specific capacitance, high power density and long life cycle. The performance of supercapacitors is evaluated by its electrode materials. Among the various supercapacitor electrode materials, recent research focused on synthesis of transition metal oxides/ hydroxides, carbon metals and polymers. Transition metal oxides such as manganese oxide $\left(\mathrm{MnO}_{2}\right)$, ruthenium oxide $\left(\mathrm{RuO}_{2}\right)$, cobalt oxide $\left(\mathrm{Co}_{3} \mathrm{O}_{4}\right)$, nickel oxides $(\mathrm{NiO})$ etc. have been widely used as supercapacitor electrode materials for storing the potential energy. In this paper, we explored the details of metal oxide material based supercapacitor electrodes and their composition via electrochemical deposition technique. We also discussed the basic parameters involved in supercapacitor studies and advantages of electrochemical deposition technique through analysis of the literature.

Keywords: Supercapacitors; Metal Oxide; Electrodeposition technique

Received 30 November 2018, Accepted 6 February 2019

DOI: $10.30919 /$ esee8c211

\section{Introduction}

Owing to the environmental issues like global warming, pollution, fuel problems, etc, it has become necessary to develop clean, efficient and sustainable energy sources for storing energy. ${ }^{1-2}$ Also many applications such as stand-by power systems, cell phones and electric hybrid vehicles require energy storage. ${ }^{3}$ In 1978 a device called supercapacitor was introduced by NCE which was used to provide the power backup for computers. ${ }^{4}$ Further it was found that these supercapacitors could be used to boost the fuel cell or battery in an electric hybrid vehicle to provide the necessary power. ${ }^{5-10}$ Recent developments have made supercapacitor as a complement of fuel cells or batteries to store the energy. ${ }^{11}$ Also it can be used in laptops, mobile phones, digital cameras, etc. ${ }^{3}$ Hence tremendous theoretical and practical research work is going on for development of supercapacitor as it can be an environmental friendly and low cost storage device. ${ }^{12-19}$

Supercapacitor consists of two identical electrodes with a separator immersed in an electrolyte. ${ }^{20}$ Electrode material plays an important role in supercapacitor. ${ }^{21,22}$ There should be an effective contact between the electrode materials and the electrolyte to achieve excellent supercapacitive properties. Transition metal oxides (2 to $50 \mathrm{~nm})$ such as $\mathrm{RuO}_{2}, \mathrm{NiO}, \mathrm{Co}_{3} \mathrm{O}_{4}, \mathrm{MnO}_{2}, \mathrm{In}_{2} \mathrm{O}_{3}, \mathrm{Fe}_{3} \mathrm{O}_{4}, \mathrm{~V}_{2} \mathrm{O}_{5}, \mathrm{IrO}_{2}, \mathrm{Bi}_{2} \mathrm{O}_{3}, \mathrm{NiFe}_{2} \mathrm{O}_{4}$, $\mathrm{BiFeO}_{3}$ etc are promising materials for the fabrication of supercapacitor

${ }^{\prime}$ Department of Electronic Science \& PG Center, Poona College of Arts, Science and Commerce, Camp, Pune, India.

${ }^{2}$ Division of Biotechnology, Chonbuk National University, Iskan 570752, Republic of Korea.

${ }^{3}$ Advanced Physics Laboratory, Department of Physics, Savitribai Phule

Pune University, Pune - 07

*E-mail: sayyed.saima26@gmail.com with high energy density due to their exceptional physic-chemical properties, suitable pore size and high specific surface area. ${ }^{23-28}$

One of the most promising techniques for fabrication of transition metal oxide is electrochemical deposition. Because of its versatility it leads to increase the specific capacitance of the supercapacitors. ${ }^{30}$ This technique is widely used as it is cheap, easy and one step technique to synthesis metal oxides, polymers and its composite. The morphology and the chemical composition of the deposited film can be easily controlled by optimizing electrochemical parameters to achieve adherent film.

There are many published review article on the supercapacitors. In literature [1,34, 37, and [97] metal oxides-based materials, conducting polymers and carbon based materials for supercapacitor electrodes are reviewed in detail. According to authors in article, ${ }^{121}$ supercapacitive performance can be enhanced by developing the nanostructure and composite materials. R.C. Ambare et al., has presented a brief review on electrode materials, also discussed their charge transport and configurations of supercapacitors. ${ }^{64}$ Evaluation of charge capacity for both negative as well as positive electrode materials was demonstrated in Ref. [66].

In this review article, we have presented synthesis of different metal oxides via electrochemical deposition used by various research groups as supercapacitor electrode material. We focused on fabrication of transition metal oxide by electrochemical deposition technique only. The main aim of this review is to give detailed information on metal oxide based supercapacitors, parameters and performance of supercapacitors.

\subsection{Fundamentals of Supercapacitors}

Supercapacitors are also known as ultracapacitors, double layer capacitors or electrochemical capacitors. They utilize large surface area and thinner dielectrics to achieve greater power density than that of 
batteries and greater capacitances with higher energy density than that of conventional capacitors. ${ }^{31-37}$ Supercapacitor reaches 20 times higher power density $(>10 \mathrm{~kW} / \mathrm{kg})$ and better life cycle $\left(>10^{5}\right.$ cycles) than that of batteries, also it can be charged/discharged rapidly. ${ }^{29,38,39}$ It can be used in various energy storage devices, either in combination with batteries or stand-alone. Fig. 1 shows the comparison between specific energy and specific power for different electrical energy storage devices. $^{40,41}$

This Ragone plot indicates that supercapacitors occupy a region between batteries and conventional capacitors. Supercapacitors are driven by the basic principle of conventional capacitors but the difference is that they have electrode material with higher surface area and have thinner dielectrics which decrease the distance between the electrodes. The capacitance ' $C$ ' is directly proportional to the surface area ' $A$ ' and inversely proportional to the distance ' $D$ ' between the electrodes:

$$
C=\varepsilon_{0} \varepsilon_{\mathrm{r}} \frac{A}{D}
$$

where, $\varepsilon_{\mathrm{r}}$ is the electrolyte dielectric constant, $\varepsilon_{0}$ is the permittivity of a vacuum. ${ }^{9}$ The stored energy $\mathrm{E}$ in a supercapacitor depends upon specific capacitance $(C)$ and the operating voltage $(V)::^{42}$

$$
E=\frac{1}{2} C V^{2}
$$

The maximum power (Pmax) depends upon operating voltage $(V)$ and the internal resistance $(\mathrm{R})$ as follows:

$$
P \max =\frac{V^{2}}{4 R}
$$

Generally, the mechanism of the supercapacitors categorizes into three types based on energy storage and cell configuration: (i) Electric Double- Layer Capacitors (EDLC's), (ii) Pseudocapacitors and (iii) Hybrid capacitors ${ }^{43}$ as shown in Fig. 2.

\section{Electric double-layer capacitors (EDLCs):}

EDLCs are made up of two carbon based porous electrode material which are separated by an insulator. A basic configuration of EDLC is shown in Fig. 3.The energy charge is stored in a non-faradaic manner; the charge storage_mechanism is based on the electrostatic charge accumulation at the electrode-electrolyte interface. ${ }^{44}, 45$ The most common electrode material is activated carbon. Carbon nano materials are having unique structures with large surface area, better electrical conductivity and high chemical \& mechanical stability. They require wide potential window, high conductivity, fast charge/discharge rate and large surface area. ${ }^{46,47}$ The specific capacitance in carbon-based electrode materials is less and hence achieving a high energy density has become a difficult task in EDLC's.

\section{Pseudocapacitors:}

Pseudo-capacitors electrostatically store the charge as compared to EDLC's. The faradaic charge transfer in Pseudocapacitors takes place at electrode-electrolyte interface. ${ }^{48-52}$ It exhibits high energy density and high specific capacitance than that of electrical double layer capacitance due to Faradic process. ${ }^{53}$ Transition metal oxides ${ }^{54}$ and conducting polymers $^{55}$ are mainly used as pseudocapacitor electrodes. It requires high surface area, large potential window, doping of the conducting polymer and fast charge/discharge rate ${ }^{56,57}$ The main disadvantage of the pseudocapacitors is low power density. ${ }^{58}$

\section{Hybrid capacitors:}

EDLC's offers large power performance and good cyclic stability while pseudocapacitors possess greater specific capacitance and energy densities. Hybrid supercapacitors are combination of both EDLC and Pseudocapacitors which offer a high energy density and fast charging

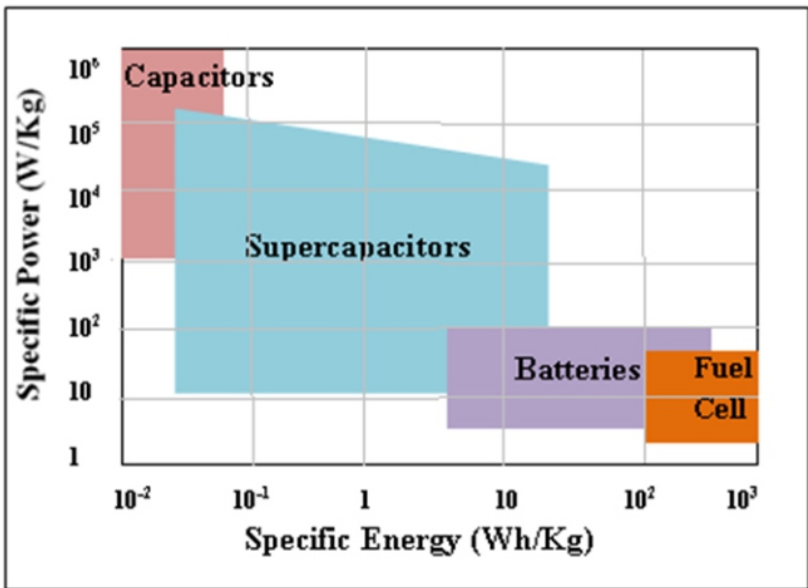

Fig. 1 Ragone plot: Specific Energy Vs Specific Power Plot.

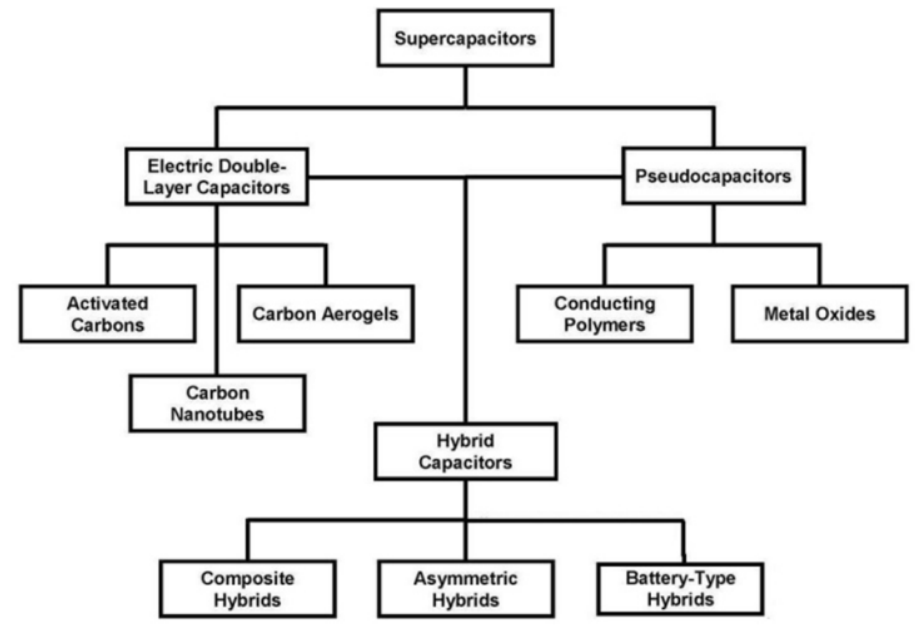

Fig. 2 Classification of Supercapacitors.

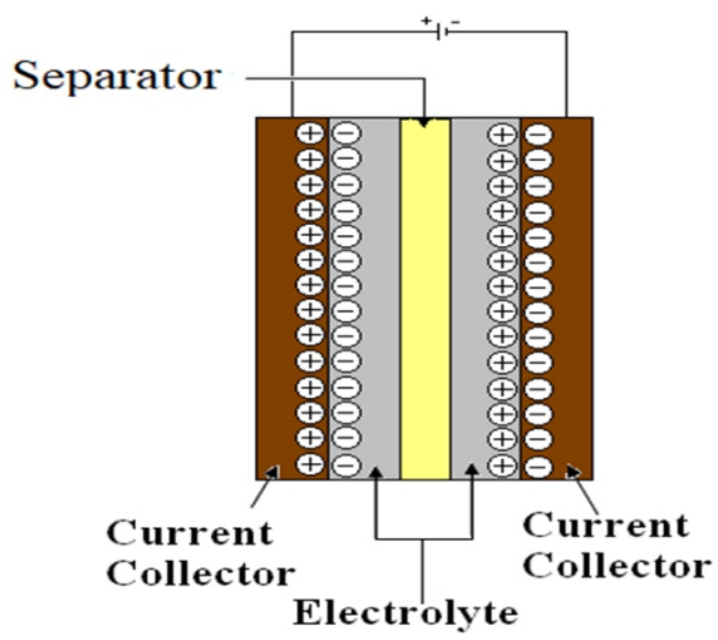

Fig. 3 Schematic diagram of EDLC. 
rate in the same cell. ${ }^{5462}$ The combination of two different electrodes typically results in more energy storage due to the wider operating voltage of an organic electrolyte and the good specific capacity of the battery type electrode. Hybrid capacitors have been tested with both negative and positive electrodes in aqueous electrolytes solution to improve the performance. ${ }^{63}$ There are three types of hybrid capacitors based on configurations of electrodes (a) composite, (b) asymmetric and (c) battery-types.

The cyclic voltammetry (CV) curve of EDLC supposed to be rectangular in shape, but in pseudo-capacitance the shape of the curve will become non-rectangular due to faradaic process as shown in Fig. 4. Hence overall shape of the CV curve in hybrid type capacitors is a nonrectangular as it is combination of both EDLC and Pseudocapacitors.

\subsection{Supercapacitive parameters}

There are various significant parameters to evaluate the performance of as prepared electrode materials for supercapacitive application as shown in Table $1 .{ }^{64-66}$
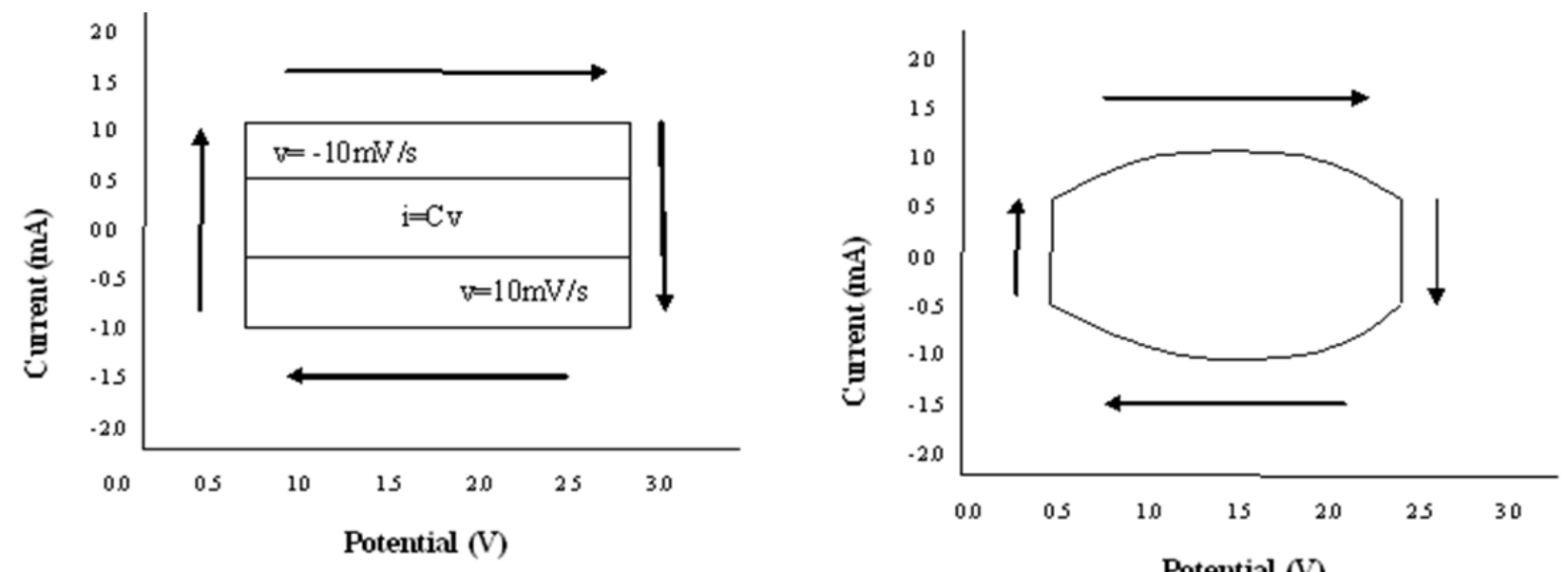

Fig. 4 Typical CV curve of EDLC and Pseudocapacitors.

Table 1 Significant parameters of Supercapacitor.

\begin{tabular}{|c|c|c|c|}
\hline Sr. No. & Parameters & Relation & Specification \\
\hline 1 & Capacitance of material & $\mathrm{C}=\frac{\mathrm{dQ}}{\mathrm{dV}}$ & $\mathrm{dQ} / \mathrm{dV}=$ rate of charge of surface charge density with electrode potential \\
\hline 2 & Double layer capacitance & $\mathrm{Cdl}=\frac{\varepsilon \mathrm{A}}{4 \pi \mathrm{t}}$ & $\begin{array}{l}\varepsilon=\text { dielectric constant of EDLC material } \\
A=\text { surface area of the electrode } \\
t=\text { thickness of electric double layer }\end{array}$ \\
\hline 3 & Voltage scan rate & $\mathrm{S}=\frac{\mathrm{dV}}{\mathrm{dt}}$ & $\mathrm{dV} / \mathrm{dt}=$ rate of change of electrode potential \\
\hline 4 & Interfacial capacitance & $\mathrm{C}_{i}=\frac{\mathrm{C}}{\mathrm{A}}$ & $\begin{array}{l}\mathrm{C}=\text { capacitance } \\
\mathrm{A}=\text { area of deposited electrode }\end{array}$ \\
\hline 5 & Specific capacitance & $\mathrm{SC}=\frac{\mathrm{C}}{\mathrm{W}}$ & $\begin{array}{l}\mathrm{C}=\text { capacitance } \\
\mathrm{W}=\text { mass of deposited electrode }\end{array}$ \\
\hline \multirow[t]{2}{*}{6} & $\begin{array}{l}\text { Average capacitance } \\
\text { (i) From CV curve }\end{array}$ & $\begin{array}{c}\mathrm{C}=\frac{\mathrm{I}}{\mathrm{dv} / \mathrm{dt}} \\
\mathrm{C}=\frac{1}{2 \mathrm{mv}}\left[\mathrm{Q}_{\mathrm{a}}+\mathrm{Q}_{\mathrm{c}}\right]\end{array}$ & $\begin{array}{l}I=\text { average current } \\
d V / d t=\text { voltage scanning rate } \\
m=\text { weight of deposited electrode } \\
v=\text { applied potential window }\end{array}$ \\
\hline & $\begin{array}{l}\text { (ii) From galvanostatic charge -discharge } \\
\text { curve }\end{array}$ & $\mathrm{C}=\frac{\mathrm{I} * \Delta \mathrm{t}}{\mathrm{m} * \Delta \mathrm{V}}$ & $\begin{array}{l}\mathrm{Qa}=\text { anodic charge in one cycle of potential sweep } \\
\mathrm{Qc}=\text { cathodic charge in one cycle of potential sweep }\end{array}$ \\
\hline 6 & Energy density and Power density & $\begin{aligned} E & =\frac{C V^{2}}{2} \\
P & =\frac{E}{t}\end{aligned}$ & $\begin{array}{l}\mathrm{C}=\text { Capacitance in farad } \\
\mathrm{V}=\text { Cell voltage in volt } \\
\mathrm{t}=\text { Discharge time in second }\end{array}$ \\
\hline 7 & Efficiency & $\eta=\frac{\mathrm{td}}{\mathrm{tc}} * 100$ & $\begin{array}{l}\mathrm{td}=\text { discharging time } \\
\mathrm{tc}=\text { charging time }\end{array}$ \\
\hline
\end{tabular}


1.3 Background of Electrodeposition technique for synthesis of Nanostructure electrode materials

Thin films play an important role in the electrochemical studies and applications. The behavior of the thin film typically $<1 \mu \mathrm{m}$ depends upon the properties of the electrode surface. There are many synthesis technique used to produce electrodes for supercapacitors such as chemical bath deposition, ${ }^{67,}{ }^{68}$ Chemical vapor deposition (CVD), ${ }^{69,} 70$ spray pyrolysis, ${ }^{71}$ SILLAR method, ${ }^{72}$ sol-gel method, ${ }^{73,74}$ hydrothermal technique $^{75}$ and electrochemical deposition etc. Among various methods, electrochemical deposition is an attractive and well known technique due to its inexpensive, simple and effective process of fabrication of the metallic coatings under ambient temperature. It is a versatile technique used for deposition of the metals, ${ }^{76,77}$ metal alloys, ${ }^{78,79}$ metal oxides ${ }^{80}$ and hybrid materials. ${ }^{81}$ The technique involves the movement of metallic ions towards a cathode in the solution driven by an electric field. The ions either accept the electron and get deposited on the cathode or lose electron and get deposited on anode in the form of atom or molecule. The general setup of electrochemical deposition is shown in Fig. $5 .^{82}$ It involves the following "electrical" terms.

a. Electrolyte- The electrolyte is a conducting medium through which the flow of electric current takes place by movement of ions. It can be aqueous, non-aqueous or molten, in presence of suitable metal and chalcogenide salts.

b. Electrode- An electrode is a conductor through which an electric current enters or leaves an electrolyte. When electrode is connected to positive terminal, it is referred as an anode and when it is connected to negative terminal it is referred as cathode. At anode, positive ions are formed or negative ions are discharged or oxidizing reactions occur. At cathode, positive ions are discharged or negative ions are formed or reducing reactions occur.

c. Electrode potential- An electrode potential is the difference in potential between an electrode and the electrolyte, measured against or referred to, an arbitrary zero of potential.

d. Equilibrium electrode potential- It is a static electrode potential when the electrode and electrolyte are in equilibrium with respect to a specified electrochemical reaction.

e. Standard electrode potential- A standard electrode potential is the equilibrium potential, for an electrode in contact with an electrolyte, in

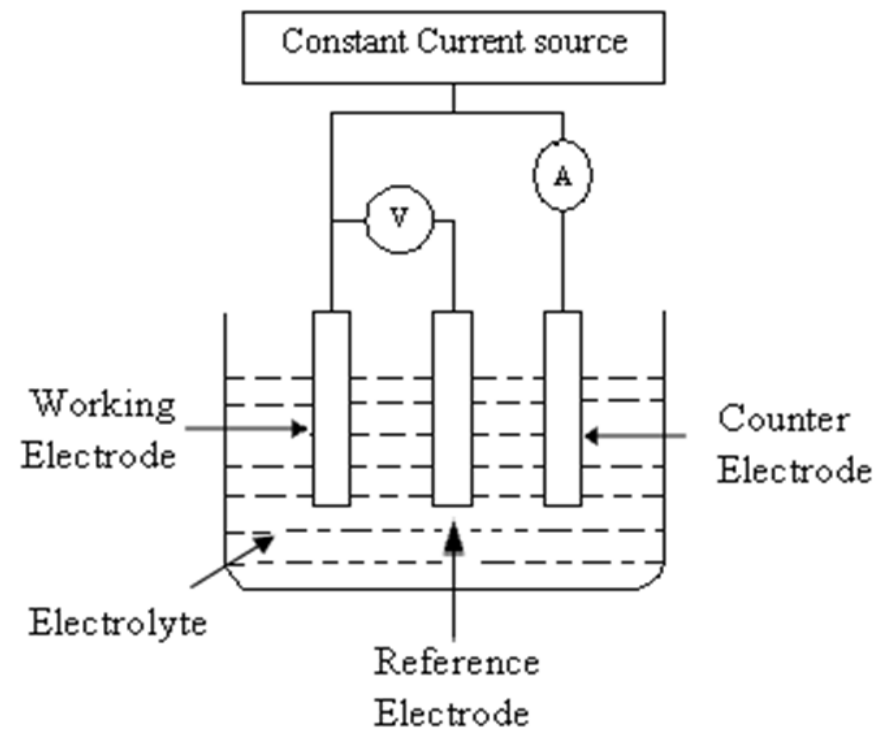

Fig. 5 Electrochemical deposition setup. which all the components of a specified electrochemical reaction are in their standard state.

f. Reference electrode- A reference electrode is defined as an electrode on which the state of equilibrium of a given reversible electrochemical reaction is permanently secured under constant physicochemical conditions. Equilibrium potential of standard hydrogen electrode is $0 \mathrm{~V}$, whereas, it is $+0.2415 \mathrm{~V}$ for saturated calomel electrode (SCE).

Electrodeposition method is an isothermal process in which, the thickness, crystallographic orientation, ${ }^{80}$ morphology, ${ }^{83,84}$ and dopant density $^{85}$ of the films can be easily controlled by electrochemical parameters such as electrode potential or current (charge), ${ }^{86}$ time, deposition temperature, electrolyte composition, ${ }^{87}$ concentration, ${ }^{89} \mathrm{pH}$ of the bath, ${ }^{90}$ etc. Thus, electrodeposition allows obtaining uniform films grown on substrate of complex shapes and areas which is not possible by other methods. One disadvantage of electrodeposition is that, it requires a conducting substrate such as glassy carbon, metals $(\mathrm{Au}, \mathrm{Pt}$, Ti, Ni, and $\mathrm{Cu}$ ), oxides (ITO, FTO) or alloys (stainless steel).

\section{Electrochemical deposition of metal oxides}

To deposit metal oxides mostly alkaline solutions with metal complex are used as an aqueous solution. Electrochemical deposition of metal oxides can be carried out under both oxidizing and reducing conditions from alkaline solutions. In both conditions, the metal ions are directly deposited on the electrode as an oxide. Deposition under oxidation condition includes the deposition of $\mathrm{MnOx}$ from $\mathrm{Mn}$ (II) ammine complex, ${ }^{91} \mathrm{CuO}$ from $\mathrm{Cu}$ (II)-tartrate, ${ }^{86} \mathrm{CeO}_{2}$ from $\mathrm{Ce}$ (III)-acetate, ${ }^{92} \mathrm{NiOx}$ from $\mathrm{Ni}(\mathrm{II})$ ammine complex ${ }^{93}$ and $\mathrm{Co}_{3} \mathrm{O}_{4}$ from $\mathrm{Co}$ (II) glycine in alkaline solutions. ${ }^{94}$ Deposition of metal oxides under reduction conditions includes deposition of $\mathrm{ZnO}^{88,}{ }^{95} \mathrm{CdO}^{96}$ and $\mathrm{Cu}_{2} \mathrm{O}$ from alkaline $\mathrm{Cu}(\mathrm{II})$ solution etc.

For supercapacitor application, metal oxide required some properties includes: (i) It should be electronically conductive. (ii) It must exist in two or more oxidation states which coexist in the continuous range without changing the phase. (iii) The protons should be freely intercalated into the oxide lattice and out of the lattice for reduction and oxidation states respectively. Till date above mentioned properties are explore for metal oxide such as manganese oxide, ruthenium oxide, nickel oxide and cobalt oxide.

\subsection{Ruthenium oxide/hydroxide and their composition}

Among the various metal oxides, both crystalline and amorphous $\mathrm{RuO}_{2}$ are promising electrode material because of excellent electrochemical capacitance $(\sim 2000 \mathrm{~F} / \mathrm{g})$, high electrical conductivity, good thermal \& chemical stability, large potential window, long life cycle and good electrochemical reversibility. ${ }^{97}{ }^{98}$ It has various forms for example nanoporous film ${ }^{67}$ nanoneedles, ${ }^{99}$ and nanoparticles. ${ }^{100}$ Ruthenium Oxide formed by various techniques including $\mathrm{CBD},{ }^{67} \mathrm{CVD},{ }^{69}$ Sol-gel method, ${ }^{101}$ Polyolmethod ${ }^{103}$ Hydrothermal, ${ }^{75}$ electrodeposition method etc. Also lots of research carried out on the combination of $\mathrm{RuO}_{2}$ with other oxides or polymers such as $\mathrm{NiO}, \mathrm{TiO}_{2}, \mathrm{VOx}, \mathrm{SnO}_{2}, \mathrm{RuO}_{2} / \mathrm{CNT}, \mathrm{RuO}_{2} /$ PPy, PANi etc. Table 2 represents the synthesis conditions with details of deposition used by various researchers to obtain the electrodeposited ruthenium oxide/hydroxide and their composition thin films.

Amorphous ruthenium oxide electrode shows different reaction in alkaline and acidic electrolyte solution for example in $\mathrm{KOH}$ electrolyte the electrode exhibited specific capacitance of $710 \mathrm{~F} / \mathrm{g}$ when calcinated at $200^{\circ} \mathrm{C}$ while in $\mathrm{H}_{2} \mathrm{SO}_{4}$ aqueous electrolyte it showed capacitance of $720 \mathrm{~F} / \mathrm{g}$ when heated at $150^{\circ} \mathrm{C}$. ${ }^{101}$ In acidic electrolyte solution, $\mathrm{RuO}_{2}$ obeys following rapid faradaic reaction: $\mathrm{RuO}_{2}^{118,119}+\mathrm{nH}^{+12}\left(\mathrm{ne} \leftrightarrow \mathrm{RuO}_{2-\mathrm{n}}(\mathrm{OH})_{\mathrm{n}}\right.$ 
Table 2 Electrochemical deposition of Ruthenium oxide/hydroxide and their composition.

\begin{tabular}{|c|c|c|c|c|c|c|c|c|c|c|c|c|}
\hline \multirow{2}{*}{$\begin{array}{l}\text { Sr. } \\
\text { No }\end{array}$} & \multirow{2}{*}{$\begin{array}{c}\text { Chemical/Bath } \\
\text { Composition \& conditions }\end{array}$} & \multicolumn{3}{|c|}{ Substrate Electrode } & \multicolumn{5}{|c|}{ Details } & \multirow[t]{2}{*}{ Remarks/Properties } & \multirow{2}{*}{$\begin{array}{c}\mathrm{SC} \\
(\mathrm{F} / \mathrm{g})\end{array}$} & \multirow[t]{2}{*}{ Ref. } \\
\hline & & A & $\mathrm{K}$ & $\mathrm{R}$ & $\begin{array}{l}\text { Applied } \\
\text { Current/ } \\
\text { Voltage }\end{array}$ & $\begin{array}{l}\text { Depo. } \\
\text { time }\end{array}$ & Temp. & $\begin{array}{l}\text { Scan } \\
\text { Rate } \\
\mathrm{mV} / \mathrm{s}\end{array}$ & Electrolyte & & & \\
\hline 1 & $\begin{array}{l}50 \text { mM Ruthenium nytril } \\
\text { of complexed by } \\
\text { ammonia }\end{array}$ & ITO & $\mathrm{Pt}$ & $\begin{array}{l}\mathrm{Ag} / \\
\mathrm{AgCl}\end{array}$ & $\begin{array}{l}0 \text { to }-1 \\
\mathrm{~V} / \mathrm{Ag}\end{array}$ & - & $\begin{array}{l}\text { Room } \\
\text { temp }\end{array}$ & 5 & $0.5 \mathrm{M} \mathrm{H}_{2} \mathrm{SO}_{4}$ & $\begin{array}{l}\text { Formation of nanograins of } \mathrm{RuO}_{2} \text { with } \\
\text { tetragonal crystal structure. }\end{array}$ & 498 & 104 \\
\hline 2 & $\begin{array}{l}0.04 \mathrm{M}\left(\mathrm{RuCl}_{3} \cdot \mathrm{xH}_{2} \mathrm{O}\right) \\
\text { After deposition the } \mathrm{RuO}_{2} \\
\text { films were dried in a } \\
\text { furnace at } 100^{\circ} \mathrm{C} \text {. }\end{array}$ & $\mathrm{Ti}$ & - & - & $5.0 \mathrm{~mA} / \mathrm{cm}^{2}$ & $\begin{array}{l}180 \\
\text { Min }\end{array}$ & $50^{\circ} \mathrm{C}$ & 10 & $0.5 \mathrm{M} \mathrm{H}_{2} \mathrm{SO}_{4}$ & $\begin{array}{l}\text { Surface morphology shows } \\
\text { cracked-mud and grains size of } \mathrm{RuO}_{2} \\
\text { is in nanometer. } \\
\text { Thickness: } 0.0014 \mathrm{~g} / \mathrm{cm}^{2} \text {. } \\
\text { The specific capacitance and energy } \\
\text { efficiency decreases with increasing } \\
\text { the film thickness. Capacitance } \\
\text { obtained from charge -discharge curve } \\
\text { is smaller due to increased ESR } \\
\text { through the presence of a separator. }\end{array}$ & 788 & 105 \\
\hline 3 & $\begin{array}{l}0.04 \mathrm{M}\left(\mathrm{RuCl}_{3} \cdot x \mathrm{H}_{2} \mathrm{O}\right) \text {, } \\
\mathrm{pH}: 2.0 \text { to } 2.5 \\
\text { After deposition } \mathrm{RuO} \\
\text { films were dried in a } \\
\text { furnace at } 373 \mathrm{~K} \text {. }\end{array}$ & $\mathrm{Pt}$ & $\mathrm{Ti}$ & - & $5.0 \mathrm{~mA} / \mathrm{cm}^{2}$ & $30 \mathrm{Min}$ & $50^{\circ} \mathrm{C}$ & 10 & $0.5 \mathrm{M} \mathrm{H}_{2} \mathrm{SO}_{4}$ & $\begin{array}{l}\mathrm{The}^{\mathrm{RuO}}{ }_{2} \text { films are nanocrystalline } \\
\text { and porous. The charging-discharging } \\
\text { behavior showed that the } \mathrm{RuO}_{2} \\
\text { electrodes were stable in the } \mathrm{H}_{2} \mathrm{SO}_{4} \\
\text { electrolyte. }\end{array}$ & 788 & 106 \\
\hline 4 & $\begin{array}{l}\mathrm{RuCl}_{3} \mathrm{xH}_{2} \mathrm{O} \\
\text { After deposition, the films } \\
\text { were dried in air }\end{array}$ & SS & Gh & SCE & $-0.45 \mathrm{~V} / \mathrm{SCE}$ & $2 \mathrm{Hr}$ & $333^{\circ} \mathrm{K}$ & 20 & $0.5 \mathrm{M} \mathrm{H}_{2} \mathrm{SO}_{4}$ & $\begin{array}{l}\text { The values of capacitance and contact } \\
\text { angle decreased because of surface } \\
\text { treatments (i.e. anodization, air }\end{array}$ & 650 & 107 \\
\hline 6 & $\begin{array}{l}0.02 \mathrm{M} \mathrm{RuCl}_{3}+0.005 \mathrm{M} \\
\mathrm{HCl} \text {, After deposition } \\
\text { heating treatment at } \\
150^{\circ} \mathrm{C} \text { for } 2 \mathrm{~h}\end{array}$ & $\begin{array}{l}\mathrm{TiO}_{2} / \\
\mathrm{Ti}\end{array}$ & $\mathrm{Pt}$ & - & $-1.0 \mathrm{~mA} / \mathrm{cm}^{2}$ & $30 \mathrm{~min}$ & $298^{\circ} \mathrm{K}$ & 10 & $1.0 \mathrm{M} \mathrm{H}_{2} \mathrm{SO}_{4}$ & $\begin{array}{l}\text { Energy dispersive peaks at } 2.25,2.61 \\
\text { and } 3.18 \mathrm{keV} \text { has been observed for } \\
\mathrm{RuO}_{2} \text { electrodes. After } 400 \text { cycles the } \\
\text { specific capacitance retained about } \\
80 \% \text { of its initial value. Nyquist plot } \\
\text { showed much lower impedance values } \\
\text { in low frequency region. }\end{array}$ & 640 & 109 \\
\hline 7 & $10 \mathrm{mMRu}(\mathrm{III}) \mathrm{Cl}_{3}$ & SS & Gh & SCE & 0 to $+1 \mathrm{~V}$ & $45 \mathrm{~min}$ & $333^{\circ} \mathrm{K}$ & 20 & $0.5 \mathrm{M} \mathrm{H}_{2} \mathrm{SO}_{4}$ & $\begin{array}{l}\text { Film was porous without any cracks } \\
\text { and pinholes. } \\
\text { Film thickness: } 0.376 \mathrm{mg} / \mathrm{cm}^{2} \cdot \mathrm{RuO}_{2} \\
\text { electrode was almost stable for } \\
\text { thousands of cycles. }\end{array}$ & 1190 & 110 \\
\hline 8 & $\begin{array}{l}5 \mathrm{mM} \mathrm{RuCl}_{3} \cdot 3 \mathrm{H}_{2} \mathrm{O}+ \\
0.01 \mathrm{M} \mathrm{HCl}+0.1 \mathrm{M} \mathrm{KCl} \text {, } \\
\text { pH: } 2.0 \\
\text { After deposition film was } \\
\text { dried in a furnace at } \\
150{ }^{\circ} \mathrm{C} \text { for } 2 \mathrm{~h} .\end{array}$ & $\mathrm{Ti}$ & $\mathrm{Pt}$ & - & $25 \mathrm{~mA} / \mathrm{cm}^{2}$ & $8 \mathrm{Min}$ & $\begin{array}{l}\text { Room } \\
\text { temp }\end{array}$ & 2 & $0.5 \mathrm{M} \mathrm{H}_{2} \mathrm{SO}_{4}$ & $\begin{array}{l}\text { The formation of uniform spherical } \\
\text { grains with nanometer in sizes and } \\
\text { porous network structure of the } \\
\mathrm{RuO}_{2} \cdot \mathrm{nH}_{2} \mathrm{O} \text {. Highest energy } \\
\text { efficiency reaches } 99.58 \% \text { obtain by } \\
\text { charge discharge curve. }\end{array}$ & 786 & 111 \\
\hline
\end{tabular}


Table 2 Electrochemical deposition of Ruthenium oxide/hydroxide and their composition.

\begin{tabular}{|c|c|c|c|c|c|c|c|c|c|c|c|c|}
\hline 9 & $\begin{array}{l}10 \mathrm{mM} \mathrm{RuCl}_{3} \cdot x \mathrm{H}_{2} \mathrm{O}+ \\
0.1 \mathrm{M} \mathrm{NaAcO}, \\
\text { After deposition films } \\
\text { were annealed in air at } \\
150^{\circ} \mathrm{C} \text { for } 2 \mathrm{~h} .\end{array}$ & $\mathrm{Ti}$ & - & - & $1.0 \mathrm{~V}$ & - & $50^{\circ} \mathrm{C}$ & 25 & $0.5 \mathrm{M} \mathrm{H}_{2} \mathrm{SO}_{4}$ & $\begin{array}{l}\text { The formation of } \mathrm{Ru} \quad \mathrm{Cl}-\mathrm{AcO} \\
\text { indicates that the deposition rate of } \\
\mathrm{RuO}_{2} \cdot x \mathrm{H}_{2} \mathrm{O} \text { from the negative shift in } \\
\text { the onset potential. It was observed } \\
\text { that film has low resistance (i.e. high } \\
\text { electronic conductivity and low } \\
\text { contact resistance between Ti and } \\
\mathrm{RuO}_{2} \cdot x \mathrm{H}_{2} \mathrm{O} \text { ). }\end{array}$ & 552 & 112 \\
\hline 10 & $\begin{array}{l}5 \mathrm{mM} \mathrm{RuCl}_{3} \cdot x \mathrm{H}_{2} \mathrm{O}+0.01 \\
\mathrm{M} \mathrm{HCl}+0.1 \mathrm{M} \mathrm{KCl} \\
\text { After deposition films } \\
\text { were dried by a cool air } \\
\text { flow. }\end{array}$ & $\mathrm{Ti}$ & $\mathrm{Pt}$ & $\begin{array}{l}\mathrm{Ag} / \\
\mathrm{AgCl}\end{array}$ & $\begin{array}{l}-200 \text { and } \\
1000 \mathrm{mV}\end{array}$ & - & $50^{\circ} \mathrm{C}$ & 50 & $0.5 \mathrm{M} \mathrm{H}_{2} \mathrm{SO}_{4}$ & $\begin{array}{l}\text { Formed film was porous with } \\
\text { amorphous structure. XPS indicates } \\
\text { material consist of mixed } \\
\text { oxyruthenium with various oxidation } \\
\text { states. } \mathrm{CV} \text { and charge -discharge curve } \\
\text { showed that the redox transitions of } \\
\text { various oxidation states on } \\
\mathrm{RuO}_{x} \cdot n \mathrm{H}_{2} \mathrm{O} \text { were electrochemically } \\
\text { reversible. The capacitance value was } \\
\text { constant up to } 120 \text { cycles. }\end{array}$ & 100 & 113 \\
\hline 11 & $\begin{array}{l}10 \mathrm{mM} \mathrm{RuCl}_{3}+0.1 \mathrm{M} \\
\mathrm{NaAcO} \\
\text { After deposition electrode } \\
\text { was annealed in air at } \\
200{ }^{\circ} \mathrm{C} \text { for } 2 \mathrm{~h}\end{array}$ & $\begin{array}{l}\text { AAO } \\
\text { coate } \\
\text { d Gh } \\
\text { or Ti }\end{array}$ & - & - & $1.0 \mathrm{~V}$ & $\begin{array}{l}10-30 \\
\text { Min }\end{array}$ & - & 4000 & $1.0 \mathrm{M} \mathrm{H}_{2} \mathrm{SO}_{4}$ & $\begin{array}{l}\text { Nanotubular structure with thickness } \\
\sim 40 \pm 5 \mathrm{~nm} \text { and Onset-overfilled } \\
\text { morphology was found. The specific } \\
\text { power and energy is equal to } 4320 \\
\mathrm{~kW} / \mathrm{kg} \text { and } 7.5 \mathrm{Wh} / \mathrm{kg} \text {, respectively. }\end{array}$ & 550 & 114 \\
\hline 12 & $\begin{array}{l}5 \mathrm{mM} \mathrm{RuCl}_{3} \cdot x \mathrm{H}_{2} \mathrm{O}+0.1 \\
\mathrm{M} \mathrm{NH} \mathrm{H}_{4} \mathrm{Cl}+0.01 \mathrm{M} \mathrm{HCl} \text {, } \\
\mathrm{pH}: 2 \text { by adding } \mathrm{NaOH} \\
\text { After deposition films } \\
\text { were annealed at } 200^{\circ} \mathrm{C} \\
\text { for } 10 \mathrm{~h}\end{array}$ & CNT & $\mathrm{Pt}$ & SCE & $\begin{array}{l}-200 \text { and } \\
1000 \mathrm{mV}\end{array}$ & - & - & 10 & $0.5 \mathrm{M} \mathrm{H}_{2} \mathrm{SO}_{4}$ & $\begin{array}{l}\text { The annealed film was of hydrous } \\
\text { form with an amorphous structure. }\end{array}$ & 1170 & 115 \\
\hline 13 & $\begin{array}{l}5 \mathrm{mM} \mathrm{RuCl}_{3} \cdot x \mathrm{H}_{2} \mathrm{O}+0.1 \\
\mathrm{M} \mathrm{NH}{ }_{4} \mathrm{Cl}+0.01 \mathrm{M} \mathrm{HCl} \text {, } \\
\mathrm{pH}: 2 \text { by adding } \mathrm{NaOH} \\
\text { After deposition films } \\
\text { were annealed at } 200^{\circ} \mathrm{C} \\
\text { for } 10 \mathrm{~h}\end{array}$ & $\begin{array}{l}\mathrm{Pt} / \mathrm{Ca} \\
/ \mathrm{CNT}\end{array}$ & $\mathrm{Pt}$ & SCE & $\begin{array}{l}-200 \text { and } \\
1000 \mathrm{mV} \text { at } \\
\text { scan rate } 50 \\
\mathrm{mV} / \mathrm{s}\end{array}$ & - & - & 10 & $0.5 \mathrm{M} \mathrm{H}_{2} \mathrm{SO}_{4}$ & $\begin{array}{l}\text { The annealed sample showed } \\
\text { crystalline amorphous structure. } \\
\text { As-prepared film was uniformly } \\
\text { deposited on the CNT substrate and } \\
\text { heterogeneously nucleated with } \sim 3 \mathrm{~nm} \\
\text { thickness and 3D nanoporous } \\
\text { structure. } \mathrm{RuO}_{2} / \mathrm{CNT} \text { electrode } \\
\text { showed overall good performance } \\
\text { compare to other electrodes. }\end{array}$ & 1170 & 116 \\
\hline 14 & $\begin{array}{l}0.01 \mathrm{M} \mathrm{RuCl}_{3} \cdot \mathrm{xH}_{2} \mathrm{O}, \\
\text { After deposition film was } \\
\text { calcinated at } 250^{\circ} \mathrm{C} \text { for } 2 \\
\text { h }\end{array}$ & $\begin{array}{l}\mathrm{Co}(\mathrm{O} \\
\mathrm{H})_{2}\end{array}$ & $\mathrm{Pt}$ & SCE & $-1 \mathrm{~V}$ & $20 \mathrm{~min}$ & $333^{\circ} \mathrm{K}$ & 20 & $30 w t \% \mathrm{KOH}$ & $\begin{array}{l}\text { XRD data showed presence of the } \\
\text { elements } \mathrm{Co}, \mathrm{O} \text { and } \mathrm{Ru} \text { with } \\
\text { tetragonal structure of both } \mathrm{RuO}{ }_{2} \text { and } \\
\mathrm{Co}_{3} \mathrm{O}_{4} \text {. Formation of mesoporous } \\
\text { morphology with particle size } 0-15 \\
\mathrm{~nm} \text {. Film was stable about } 96 \% \text { after } \\
5000 \text { charge discharge cycles. }\end{array}$ & 905 & 117 \\
\hline 15 & $\begin{array}{l}10 \mathrm{mMRuCl}_{3} \cdot \mathrm{xH}_{2} \mathrm{O}+0.1 \\
\mathrm{M} \mathrm{NaAcO} \\
\text { After deposition dried at }\end{array}$ & $\begin{array}{l}\text { AAO } \\
\text {-coat } \\
\text { edGh }\end{array}$ & $\begin{array}{l}\mathrm{SH} \\
\mathrm{E}\end{array}$ & $\begin{array}{l}\mathrm{Ah} / \\
\mathrm{Ag} / \\
\mathrm{AgCl}\end{array}$ & $1.0 \mathrm{~V}$ & $\begin{array}{l}10-30 \\
\min \end{array}$ & - & 1000 & $1 \mathrm{M} \mathrm{H}_{2} \mathrm{SO}_{4}$ & $\begin{array}{l}\text { Structure of formed film reduces the } \\
\text { diffusion resistance and increases the } \\
\text { facility of ion transportation also }\end{array}$ & 1300 & 102 \\
\hline
\end{tabular}


Where $0 \leq n \leq 2$, according to above eq (16) in acidic solution, oxidation states of $\mathrm{Ru}$ can change from $\mathrm{Ru}(\mathrm{II})$ to $\mathrm{Ru}(\mathrm{IV})$. But in an alkaline solution, changes of oxidation states for $\mathrm{RuO}_{2}$ are different. It has been reported that $\mathrm{RuO}_{2}$ composite with carbon electrode will be oxidized to $\mathrm{RuO}_{4}{ }^{2-}, \mathrm{RuO}_{4}^{-}$and $\mathrm{RuO}_{4}$ and reduced to $\mathrm{RuO}_{2}$. ${ }^{120,121}$

The performance of $\mathrm{RuO}_{2}$ depends upon crystallinity, surface area, combination of water, temperature and size of particle. The crystallinity depends on the synthesis technique which affects the supercapacitive performance of $\mathrm{RuO}_{2}$. Amorphous $\mathrm{RuO}_{2}$ thin films formed by anodic deposition showed maximum capacitance of $1190 \mathrm{~F} / \mathrm{g}$ in $\mathrm{H}_{2} \mathrm{SO}_{4}$ electrolyte for 10 cycles, as number of cycles increases capacitance decrease upto $\sim 800 \mathrm{~F} / \mathrm{g}$ for 1000 cycles. ${ }^{110}$ To increase capacitance value one of the most effective way is to increase the surface area. ${ }^{101}$ The unique electrochemical features result in CV curve as shown in Fig. 6. The figure indicates an ideal capacitive behavior. ${ }^{104}$ As reported in ref [105] the specific capacitance and energy efficiency decreases with increasing the film thickness. Combination of water with $\mathrm{RuO}_{2}$ is used to enrich the diffusion of cations inside the electrode layer. As reported in Ref [111] hydrous ruthenium oxide $\left(\mathrm{RuO}_{2} \cdot \mathrm{nH}_{2} \mathrm{O}\right)$ formed by cathodic electrodeposition showed a capacitance of $786 \mathrm{~F} / \mathrm{g}$. Whereas $\mathrm{RuO}_{2} \cdot \mathrm{nH}_{2} \mathrm{O}$ formed by anodic deposition showed specific capacitance of $552 \mathrm{~F} / \mathrm{g}$ when heated at $150{ }^{\circ} \mathrm{C}$ for $2 \mathrm{hr}$. ${ }^{112} \mathrm{The} \mathrm{RuO}_{2} \cdot \mathrm{nH}_{2} \mathrm{O}$ nanotubular array electrode formed by using anodic deposition exhibits $\mathrm{SC}$ as high as $1300 \mathrm{~F} / \mathrm{g}$ along with an energy density of $7.5 \mathrm{Wh} / \mathrm{kg}$. ${ }^{102}$ Annealing Temperature is another most important factor for electrochemical performance, $\mathrm{RuO}_{2}$ electrode was prepared by cathodic electrodeposition on $\mathrm{Ti}$ substrate exhibits maximum capacitance of $788 \mathrm{~F} / \mathrm{g}$ when calcinated at $100^{\circ} \mathrm{C} .{ }^{105} \mathrm{Kim}$ et al., has reported that the electrochemically prepared composition of $\mathrm{RuO}_{2}$ with carbon nanotube film exhibits much higher capacitance of $1170 \mathrm{~F} / \mathrm{g} .{ }^{115}$

In summary, the composition of $\mathrm{RuO}_{2}$ with carbon nanotube based electrode improves the supercapacitive performance. Even though $\mathrm{RuO}_{2}$ showed extremely high specific capacitance but it is not suitable for commercial application due to its relatively high cost and environmental harmfulness. There are two ways to reduce the cost: (i) by composing
$\mathrm{RuO}_{2}$ with other metal oxide. (ii) depositing $\mathrm{RuO}_{2}$ on low cost substrate.

\subsection{Manganese oxide/hydroxide and their composition}

Manganese oxide $\left(\mathrm{MnO}_{2}\right)$ shows all over good electrochemical performance that why it has been widely used as an electrode materials for supercapacitor applications. Manganese oxide is an alternative to replace $\mathrm{RuO}_{2}$ because of their low toxicity, low cost, and high theoretical capacitances value between 1100 to $1300 \mathrm{~F} / \mathrm{g}$ and long cycle life $\sim 10,000$ cycles. ${ }^{122-131}$ Many efforts have been made to obtain mesoporous $\mathrm{MnO}_{2}$ by using different synthesis techniques includes CBD, SILAR method, template method, hydrothermal, ultrasound irradiation and electrodeposition method. ${ }^{132-134}$ Table 3 presents the summary of synthesis condition with deposition details electrodeposited manganese oxide /hydroxide and their composition thin films.

$\mathrm{MnO}_{2}$ has various oxidation states, such as $\mathrm{Mn}(0), \mathrm{Mn}(\mathrm{II}), \mathrm{Mn}(\mathrm{III})$, $\mathrm{Mn}(\mathrm{IV}), \mathrm{Mn}(\mathrm{V}), \mathrm{Mn}(\mathrm{VI})$, and $\mathrm{Mn}(\mathrm{VII})^{171}$ with several crystal structures like $\alpha, \beta, \gamma, \delta{ }^{172}$ Following two mechanisms show the charge behavior of $\mathrm{MnO}_{2}$ which involve a redox reaction of oxidation states between the III and IV of Mn.

$$
\begin{gathered}
\mathrm{MnO}_{2}+\mathrm{C}^{+}+\mathrm{e}^{-} \leftrightarrow \mathrm{MnOOC} \\
\left(\mathrm{MnO}_{2}\right)_{\text {surface }}+\mathrm{C}^{+}+\mathrm{e}^{-} \leftrightarrow(\mathrm{MnOOC})_{\text {surface }}
\end{gathered}
$$

Equ (17) indicates the insertion of electrolyte cations like $\mathrm{H}^{+}=\mathrm{C}^{+}, \mathrm{Na}^{+}$, $\mathrm{Li}^{+}$, and $\mathrm{K}^{+}$in the bulk material and equ (18) implies that the surface adsorption of electrolyte cations on the $\mathrm{MnO}_{2}$ electrode. ${ }^{173,174}$

Electrochemical performance of $\mathrm{MnO}_{2}$ depends upon some important factors includes Morphology, Crystallinity, Crystal Structure, Thickness of the electrode and Surface area.

a. Morphology: The Morphology of film depends upon synthesis process and conditions. Dubal et al., ${ }^{138}$ has prepared the $\mathrm{MnO}_{2}$ thin film by different modes of electrochemical deposition, it was found that significant change in the surface morphologies due to different modes. Four different morphologies i.e. nanonods, nanospheres, nanosheets and nanoflowers of $\mathrm{MnO}_{2}$ were demonstrated by varying current density and concentration of $\mathrm{H}_{2} \mathrm{SO}_{4}$. It was found that highest capacitance of 362.5 $\mathrm{F} / \mathrm{g}$ for nanonode electrode at $0.5 \mathrm{~A} / \mathrm{g}$. ${ }^{147}$

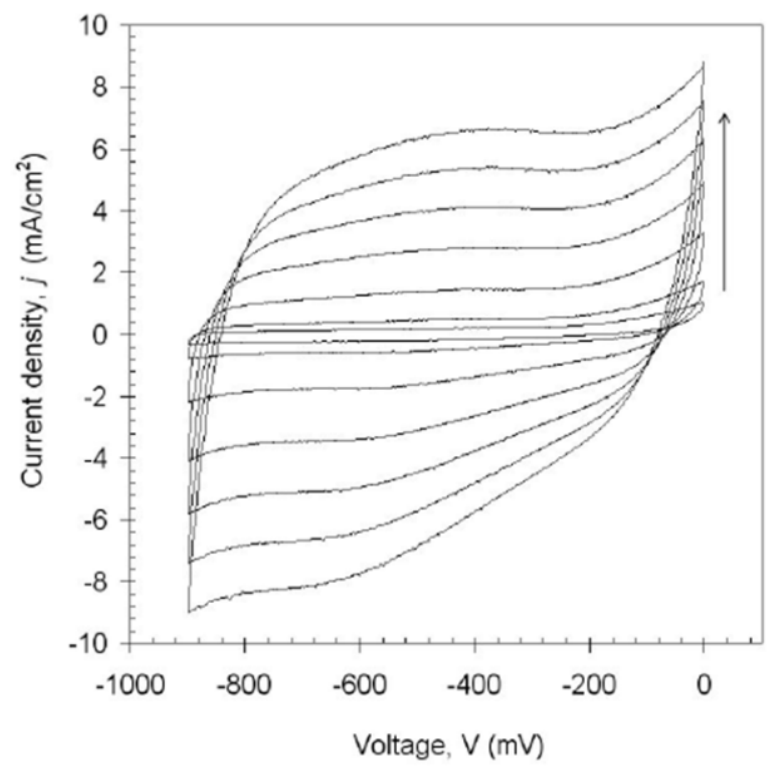

Fig. 6 The $\mathrm{CV}$ curves of $\mathrm{RuO}_{2}$ electrode at different scanning rates in $0.5 \mathrm{M} \mathrm{H}_{2} \mathrm{SO}_{4}$ electrolyte. Reproduce from Ref [104].

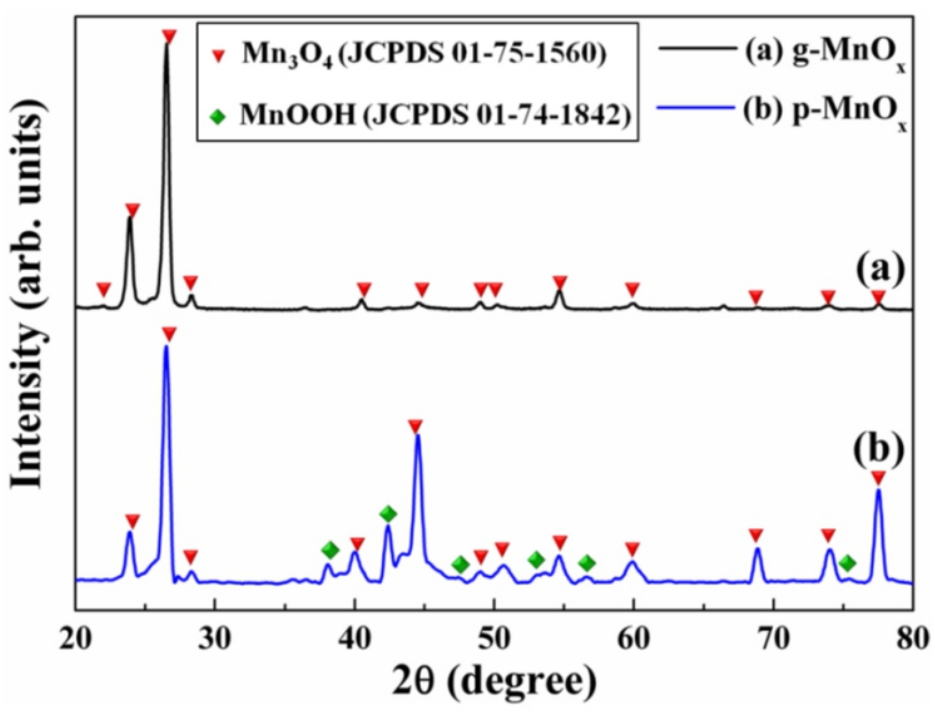

Fig. 7 XRD patterns of (a) g-MnOx and (b) p-MnOx. Reproduced from Ref. [141]. 
b. Crystallinity: Alike to $\mathrm{Ru}_{\mathrm{O} 2}$ cystallinity depends upon synthesis process. High crystallinity gives increase in conductivity but decrease in surface area. To achieve greater conductivity annealing temperature plays an important role. Chang et al. ${ }^{135}$ has investigated effect of heat treatment on material. Amorphous oxide film converted into fibrous shape with nanocrystalline when calcinated at $200^{\circ} \mathrm{C}$ for $2 \mathrm{~h}$. However at high temp $\left(400^{\circ} \mathrm{C}\right)$ formed films indexed to $\mathrm{Mn}_{3} \mathrm{O}_{4}$ and $\mathrm{Mn}_{2} \mathrm{O}_{3}$.

c. Crystal structure: The performance of electrode also depends upon crystal structure. It is observed that the various synthesis conditions can results in the different structures of $\mathrm{MnO}_{\mathrm{x}}$. Three types of crystal structures for $\mathrm{MnO}_{2}$ were demonstrated, $\varepsilon-\mathrm{MnO}_{2}$ prepared without any complex agent, defective rock salt $\mathrm{MnO}_{2}$ from EDTA containing solutions, and defective antifluorite $\mathrm{MnO}_{2}$ from citrate containing solutions. It was found that the defective rock salt and antifluorite structures of $\mathrm{MnO}_{2}$ exhibit better capacitive properties than that off $\varepsilon$ $\mathrm{MnO}_{2}$. Whereas in Ref [141] GS deposition mode indexed to tetragonal phase of $\mathrm{Mn}_{3} \mathrm{O}_{4}$ while pulse current mode indexed to two structures i.e. tetragonal $\mathrm{Mn}_{3} \mathrm{O}_{4}$ and orthorhombic $\mathrm{MnOOH}$ as shown in Fig. 7 (XRD patterns). It was observed that the pulse current deposition mode showed better capacitive properties. d. Thickness and surface area: As thickness increases the specific capacitance decreases. Qiu et al., ${ }^{140}$ has reported that the formation of $\mathrm{Mn}_{\mathrm{O} 2}$ film with thickness of $0.58 \sim 1.25 \mu \mathrm{m}$ and the specific surface area of as-prepared sample was $7.7^{\mathrm{m} 2} / \mathrm{g}$. Wanchaem et al., has prepared $\mathrm{MnOx}$ by two precursors i.e. $\mathrm{MnS}_{\mathrm{O} 4}$ and $\mathrm{KMn}_{\mathrm{O4}}$. The highest specific capacitance was found by using $\mathrm{MnS}_{\mathrm{O4}}$ as a precursor due to its nanosheet structure with a large surface area. ${ }^{142}$

In literature ${ }^{146}$ amorphous $\mathrm{MnOx} \cdot n \mathrm{H}_{2} \mathrm{O}$ is fabricated by three different modes i.e. potentiostatic, galvanostatic, and potentiodynamics. It was observed that all deposits showed similar capacitive properties because of similar oxidation states. ${ }^{154}$ Rusi et al., has fabricated composition of $\mathrm{MnO}_{2}$ with $\mathrm{NiO}$ by three different modes of electrochemical deposition. The best electrochemical performance of $\mathrm{CV}$ mode was found in mixed $\mathrm{KOH} / \mathrm{K}_{3} \mathrm{Fe}(\mathrm{CN})_{6}$ electrolyte in comparison with $\mathrm{Na}_{2} \mathrm{SO}_{4}$ electrolyte. The maximum specific capacitance of $3509 \mathrm{~F} / \mathrm{g}$ was found. ${ }^{158}$ Whereas in same electrolyte (mixed $\left.\mathrm{KOH} / \mathrm{K}_{3} \mathrm{Fe}(\mathrm{CN})_{6}\right)$ electrodeposited $\mathrm{rGO} / \mathrm{MnO}_{2}$ nanocomposite electrode exhibits specific capacitance as high as $13,333 \mathrm{~F} / \mathrm{g}$ with power density of $68.35 \mathrm{~kW} / \mathrm{kg}$ and energy density of $1851 \mathrm{Wh} / \mathrm{kg} .{ }^{159}$ Fig. 8 and 9 represent a typical charge discharge, $\mathrm{CV}$ curve and cyclic stability of
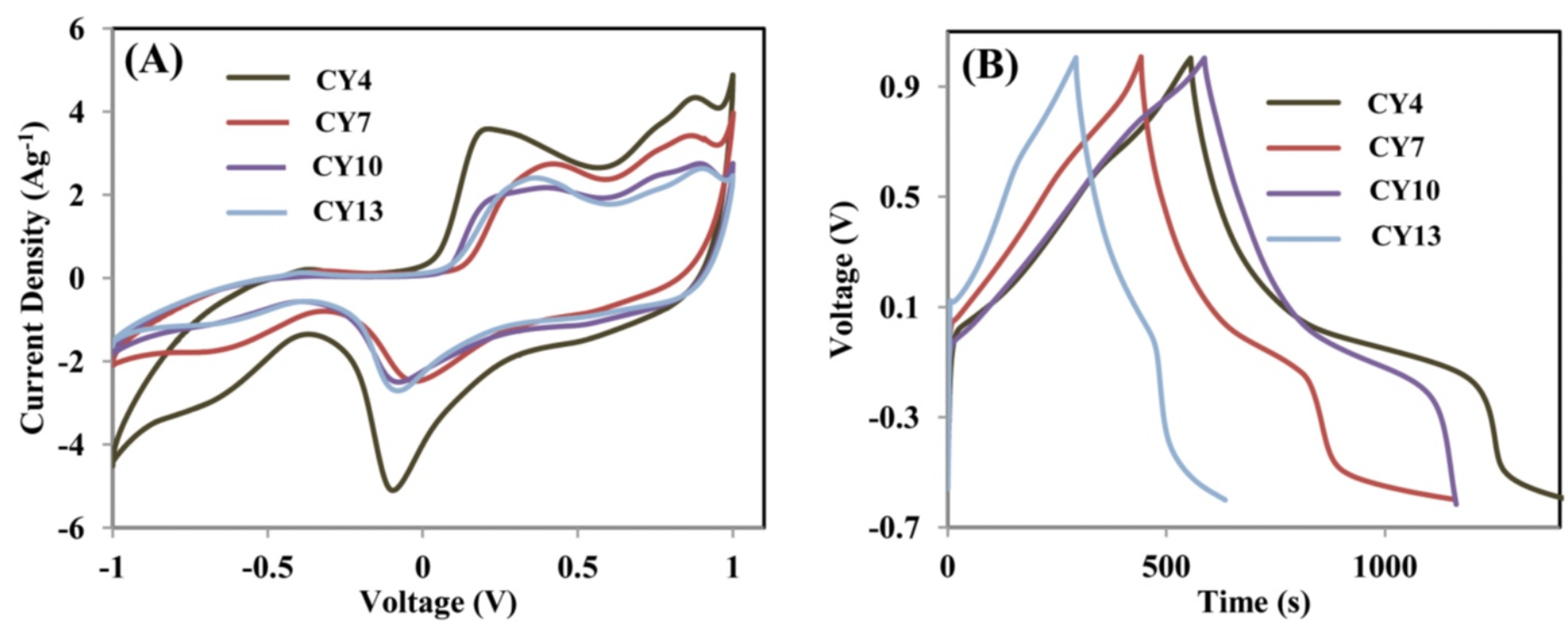

Fig. 8 (A) CV curve and (B) Charge-discharge curve of $\mathrm{MnO}_{2}-\mathrm{NiO}$ Composite electrode. Reproduced from ref. [158].
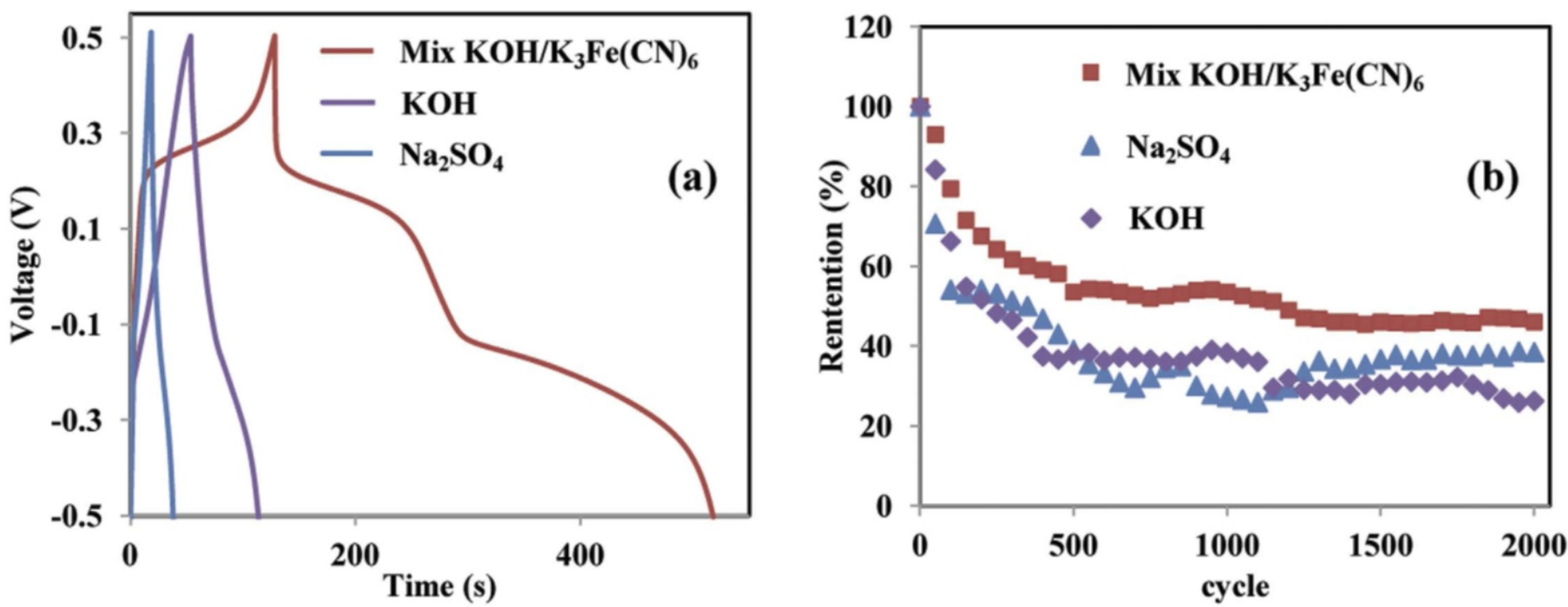

Fig. 9 Charge-discharge curve and (b) Cyclability of $\mathrm{rGO} / \mathrm{MnO}_{2}$ nanocomposites electrode in three different electrolytes. Reproduced from ref. [159]. 
$\mathrm{MnO}_{2}-\mathrm{NiO}$ composite and $\mathrm{rGO} / \mathrm{MnO}_{2}$ nanocomposites respectively. ${ }^{158,159}$

In conclusion, one can increase the specific capacitance, energy and power densities by depositing $\mathrm{MnO}_{2}$ onto carbon material with large surface area and high conductivity. The composition of $\mathrm{NiO}$ with $\mathrm{MnO}_{2}$ is versatile, cost efficient and scalable for supercapacitor applications. Addition of glucose with $\mathrm{MnO}_{2}$ can give rise in specific capacitance, energy and power densities.

\subsection{Nickel oxide/hydroxide and their composition}

Nickel oxide/hydroxide electrode plays an important role in fabrication of supercapacitors because of its high specific capacitance (theoretically $\sim 3750 \mathrm{~F} / \mathrm{g}$ ), easy synthesis, high chemical and thermal stabilities, environment friendliness and low cost. ${ }^{175-179} \mathrm{NiO}$ has several nanostructures such as nanorods, nanowires, nanobelts, and nanoflowers. Literature analysis for synthesis conditions with deposition details of Nickel oxide/hydroxide and their composition thin films via electrodeposition technique is shown in Table 4.

The redox reaction of $\mathrm{NiO}$ in an alkaline electrolyte can be described as follows: ${ }^{186-188}$

$$
\mathrm{NiO}+\mathrm{OH}^{-} \leftrightarrow \mathrm{NiOOH}+\mathrm{e}^{-}
$$

The electrochemical performance of $\mathrm{NiO}$ totally depends upon Crystallinity which affects by heating treatment. Wu et al., has reported that the nickel hydroxide electrodeposited on nickel substrate was transformed into the nickel oxide when calcinating at $250^{\circ} \mathrm{C}$, which exhibits high SC of $1478 .{ }^{180}$ In literature ${ }^{182} \mathrm{NiO}$ electrode obtained from three precursors i.e. nitrate, chloride and sulphate. It was observed that the $\mathrm{NiO}$ electrode prepared from sulphate solution showed all over good electrochemical performance. Particle-like nickel hydroxide prepared by electrodeposition technique exhibits the maximum specific capacitance of $2595 \mathrm{~F} / \mathrm{g}$. ${ }^{184}$

Because of high specific capacitance and low cost of $\mathrm{Ni} / \mathrm{Ni}(\mathrm{OH})_{2}$, it should be promising electrode materials for supercapacitor applications. But there are two main disadvantages of using $\mathrm{NiO}$ for supercapacitor electrode (i) it has poor cyclic stability. (ii) low electric conductivity. To overcome these drawbacks, composing $\mathrm{NiO}$ with other materials and fabricating nanostructured $\mathrm{NiO}$ are advisable.

\subsection{Cobalt oxide/hydroxide and their composition}

Cobalt oxide $\left(\mathrm{Co}_{3} \mathrm{O}_{4}\right)$ has a cubic structure and most studied material due to their high electrical conductivity, large surface area, excellent reversible redox behavior and long-term stability with high theoretical capacitances value $(\sim 3560 \mathrm{~F} / \mathrm{g}) .{ }^{189-196}$ Table 5 presents the summary of synthesis conditions with deposition details used by various researchers for obtaining electrodeposited Cobalt oxide /hydroxide and their composition thin films.

The redox reaction of $\mathrm{Co}_{3} \mathrm{O}_{4}$ in alkaline electrolyte can be expressed as follows: ${ }^{202,203}$

$$
\begin{gathered}
\mathrm{Co}_{3} \mathrm{O}_{4}+\mathrm{OH}^{-}+\mathrm{H}_{2} \mathrm{O} \leftrightarrow 3 \mathrm{CoOOH}+\mathrm{e}^{-} \\
\mathrm{CoOOH}+\mathrm{OH} \leftrightarrow \mathrm{CoO}_{2}+\mathrm{H}_{2} \mathrm{O}+\mathrm{e}^{-}
\end{gathered}
$$

Nanocrystalline $\mathrm{Co}_{3} \mathrm{O}_{4}$ film was formed by electrodeposition method exhibits specific power and energy of $1.33 \mathrm{~kW} / \mathrm{kg}$ and $4.0 \mathrm{Wh} / \mathrm{kg}$ respectively. ${ }^{197}$ Jagadale et al., has prepared cobalt oxide by three different modes of electrodeposition technique. Film deposited by PS mode showed maximum values of specific capacitance, specific energy and specific power as compare to PD and GS modes. ${ }^{199}$ Aghazadeh et al., has prepared $\beta$ - cobalt hydroxide with flake-like morphology by green electrochemical synthesis as shown in Fig. 10 (TEM image) exhibits the specific capacitance of $1288.1 \mathrm{~F} / \mathrm{g} .^{200}$ Rajeswari et al., has prepared cobalt hydroxide nanoplates on cadmium oxide $(\mathrm{CdO})$ as conducting base electrode exhibits high capacitance value of $1119 \mathrm{~F} / \mathrm{g} .{ }^{201}$

In conclusion, $\mathrm{Co}(\mathrm{OH})_{2}$ electrodes showed good performance as compare to $\mathrm{Co}_{3} \mathrm{O}_{4}$. However, both $\mathrm{NiO} / \mathrm{Ni}(\mathrm{OH})_{2}$ and $\mathrm{Co}_{3} \mathrm{O}_{4} / \mathrm{Co}(\mathrm{OH})_{2}$ have same drawbacks, which limits their practical use.

\subsection{Other metal oxides}

Other than $\mathrm{RuO}_{2}, \mathrm{MnO}, \mathrm{NiO}$ and $\mathrm{Co}_{3} \mathrm{O}_{4}$ electrodes, copper oxide $(\mathrm{CuO}),{ }^{204207}$ Vanadium oxide $\left(\mathrm{V}_{2} \mathrm{O}_{5}\right),{ }^{208,209}$ Molybdenum oxide $\left(\mathrm{MoO}_{\mathrm{x}}\right),{ }^{210}$ ${ }^{211}$ Titanium oxide $\left(\mathrm{TiO}_{2}\right)$, ${ }^{212},{ }^{213}$ Tin oxide $\left(\mathrm{SnO}_{2}\right),{ }^{214} \mathrm{Bi}_{2} \mathrm{O}_{3},{ }^{215}$ Iron oxides $\left(\mathrm{Fe}_{2} \mathrm{O}_{3} / \mathrm{Fe}_{3} \mathrm{O}_{4}\right)^{216}$ and Indium Oxide $\left(\operatorname{In}_{2} \mathrm{O}_{3}\right)$ have been studied for supercapacitor electrode materials.

Amorphous copper oxide thin films have been synthesized by electrodeposition on different substrate for example copper oxide grown on copper foam exhibits maximum capacitance of $212 \mathrm{~F} / \mathrm{g}^{206}$ while on stainless steel substrates showed specific capacitance of 36 and $179 \mathrm{~F} / \mathrm{g}$ in $1 \mathrm{M} \mathrm{Na}_{2} \mathrm{SO}_{4}$ electrolyte. ${ }^{204,}{ }^{205}$ Ghadge et al., has reported the copper hydroxide thin film electrode formed by anodization method exhibits maximum specific capacitance of $6000 \mathrm{~F} / \mathrm{g} .{ }^{207} \mathrm{TiO}_{2}$ has been deposited via electrochemical anodization technique on Titanium metal foil showed specific capacitance of $1300 \mu \mathrm{F} / \mathrm{cm}^{2} .{ }^{217}$ Lee et al., has reported that the amorphous $\mathrm{V}_{2} \mathrm{O}_{5}$ exhibits a maximum specific capacitance of $350 \mathrm{~F} / \mathrm{g} .{ }^{218}$ Amorphous MoOx film formed by electrodeposition technique showed capacitance as high as $507 \mathrm{~F} / \mathrm{g}$ in $1 \mathrm{M} \mathrm{H}_{2} \mathrm{SO}_{4}$ electrolyte. ${ }^{219}$ Electrodeposited $\mathrm{Bi}_{2} \mathrm{O}_{3}$ thin film on copper substrate exhibits specific capacitance of $98 \mathrm{~F} / \mathrm{g} .{ }^{220}$ Amorphous $\mathrm{SnO}_{2}$ exhibits the maximum specific capacitance of $285 \mathrm{~F} / \mathrm{g}$ synthesized by electrochemical deposition method. ${ }^{221}$ Prasad et al., has prepared $\operatorname{In}_{2} \mathrm{O}_{3}$ film via electrochemical deposition method which exhibited a specific capacitance of $190 \mathrm{~F} / \mathrm{g} .22$

\section{Conclusion}

Supercapacitors have emerged as an alternative solution to energy technology with higher energy density, excellent electrochemical properties and good cyclic stability. Due to its large surface area thinner dielectric and higher thermal \& electrochemical conductivity, it can be used in many application such as emergency power supplies, specific power systems, back-up and pulse power applications. Also there has been great interest in developing supercapacitors for electric hybrid vehicles power systems. Supercapacitor can be easily fabricated using various transition metal oxides/hydroxides due to their high

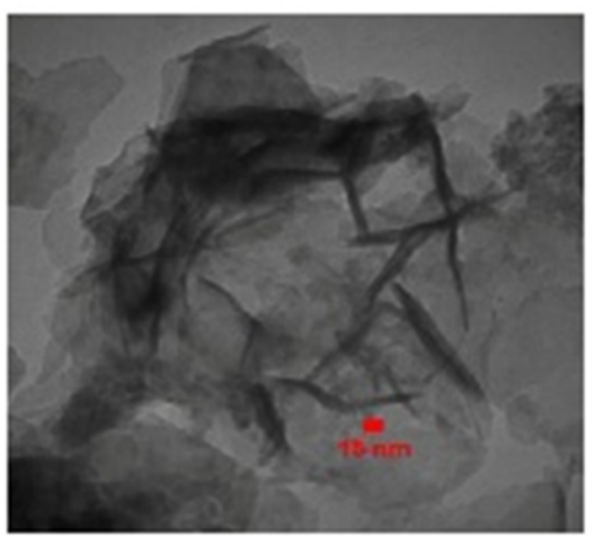

Fig. 10 TEM image of $\beta$ - cobalt hydroxide with flake-like morphology. Reproduced from ref. [200]. 
conductivity, larger surface area, and better stability. We have reviewed the various transition metal oxides/hydroxides used for supercapacitor via electrochemical deposition. The high performance of supercapacitors could be achieved by metal oxide/hydroxides electrodes with composite materials. Key challenges for supercapacitor are their limited energy and power densities. To overcome this problem, researchers should focus to develop new electrode materials with high capacitance, energy and power densities and wider potential range. For these electrode materials should have low internal resistance, suitable pore size, high surface area and better electrochemical \& mechanical stability. Hence this area requires further research and development for supercapacitors to become a realistic power solution.

Table 3 Electrochemical deposition of Manganese oxide/hydroxide and their composition.

\begin{tabular}{|c|c|c|c|c|c|c|c|c|c|c|c|c|}
\hline \multirow{2}{*}{$\begin{array}{l}\text { Sr. } \\
\text { No }\end{array}$} & \multirow{2}{*}{$\begin{array}{c}\text { Chemical/Bath } \\
\text { Composition \& conditions }\end{array}$} & \multicolumn{3}{|c|}{ Substrate Electrode } & \multicolumn{5}{|c|}{ Details } & \multirow[t]{2}{*}{ Remarks/Properties } & \multirow{2}{*}{$\begin{array}{c}\mathrm{SC} \\
(\mathrm{F} / \mathrm{g})\end{array}$} & \multirow[t]{2}{*}{ Ref. } \\
\hline & & A & K & $\mathrm{R}$ & $\begin{array}{c}\text { Applied } \\
\text { Current/Volta } \\
\text { ge }\end{array}$ & $\begin{array}{c}\text { Depo. } \\
\text { time }\end{array}$ & Temp. & $\begin{array}{l}\text { Scan } \\
\text { Rate } \\
\mathrm{mV} / \mathrm{s}\end{array}$ & Electrolyte & & & \\
\hline 1 & $\begin{array}{l}0.5 \mathrm{M} \mathrm{Mn}\left(\mathrm{CH}_{3} \mathrm{COO}\right)_{2} \text {, } \\
\text { After deposition film was } \\
\text { annealed up to } 600^{\circ} \mathrm{C} \text { for } 2 \\
\text { h. }\end{array}$ & Gh & $\mathrm{Pt}$ & SCE & $0.5 \mathrm{~V}$ & - & $25^{\circ} \mathrm{C}$ & - & $2 \mathrm{M} \mathrm{KCl}$ & $\begin{array}{l}\text { Amorphous film transformed into a } \\
\text { fibrous structure with dispersive } \\
\text { nanocrystals after annealing at } 200^{\circ} \mathrm{C} \text { for } \\
2 \mathrm{~h} \text {. When the temperature increased to } \\
400^{\circ} \mathrm{C} \text {, partial crystallization of } \mathrm{Mn}_{3} \mathrm{O}_{4} \\
\text { and nanocrystalline } \mathrm{Mn}_{2} \mathrm{O}_{3} \text { was found. It } \\
\text { was observed that the growth of oxide } \\
\text { particles, without crystalline structure } \\
\text { changed as the annealing temperature } \\
\text { was increased to } 600^{\circ} \mathrm{C} \text {. Electrode } \\
\text { annealed at } 200^{\circ} \mathrm{C} \text { was stable up to } 500 \\
\text { cycles. }\end{array}$ & 202 & 135 \\
\hline 2 & $20 \mathrm{mM} \mathrm{KMnO}_{4}$ & SS & $\mathrm{Pt}$ & $\begin{array}{l}\mathrm{Ag} / \\
\mathrm{AgCl}\end{array}$ & $\begin{array}{l}0.5 \text { to } 1 \\
\mathrm{~mA} / \mathrm{cm}^{2}\end{array}$ & $\begin{array}{l}0.5 \\
\text { hour }\end{array}$ & - & 10 & $\begin{array}{l}0.5 \mathrm{M} \\
\mathrm{Na}_{2} \mathrm{SO}_{4}\end{array}$ & $\begin{array}{l}\text { XRD showed that, the formation of } \\
\text { amorphous } \mathrm{MnO}_{2} \text { film. Capacitive } \\
\text { performance of the films was increased } \\
\text { with the increase in deposition current } \\
\text { density. Specific capacitance slightly } \\
\text { decreases after } 300 \text { cycles. }\end{array}$ & 174 & 136 \\
\hline 3 & $0.02-0.1 \mathrm{M} \mathrm{KMnO}_{4}$ & $\begin{array}{l}\mathrm{Ni} \text {, } \\
\text { mes } \\
\text { hes, }\end{array}$ & $\mathrm{Pt}$ & - & $2 \mathrm{~mA} / \mathrm{cm}^{2}$ & $10 \mathrm{~min}$ & - & 2 & $\begin{array}{l}0.5 \mathrm{M} \\
\mathrm{Na}_{2} \mathrm{SO}_{4} \text { and } \\
0.5 \mathrm{M} \mathrm{K}_{2} \mathrm{SO}_{4}\end{array}$ & $\begin{array}{l}\text { Films were amorphous, nearly spherical } \\
\text { with the size } \sim 30 \mathrm{~nm} \text {, while some } \\
\text { particles of } \sim 100 \mathrm{~nm} \text { were also seen. }\end{array}$ & 240 & 137 \\
\hline 4 & $\begin{array}{l}0.1 \mathrm{M} \text { manganese } \\
\text { sulphate }+0.1 \mathrm{M} \text { citric } \\
\text { acid, pHof } \sim 10.5 \text { by } \\
\text { adding } 1 \mathrm{M} \mathrm{NaOH} \text {. }\end{array}$ & SS & Gh & SCE & $\begin{array}{l}\text { PD mode: } \\
+1.3 \text { and }-1.2 \\
\mathrm{~V} \\
\text { PS mode: } \\
+1.1 \mathrm{~V} \\
\mathrm{GS} \text { mode: } \\
5 \mathrm{~mA} / \mathrm{cm}^{2}\end{array}$ & - & - & 20 & $1 \mathrm{M} \mathrm{Na}_{2} \mathrm{SO}_{4}$ & $\begin{array}{l}\text { All electrodes revealed that the } \\
\text { formation of amorphous phase. Different } \\
\text { modes significantly affect the surface } \\
\text { morphology of } \mathrm{MnO}_{2} \text { films. TEM } \\
\text { showed that, the growth of the film was } \\
\text { cluster by cluster with nanocrystals. The } \\
\text { film for PD mode shows overall good } \\
\text { performance. }\end{array}$ & 237 & 138 \\
\hline 5 & $\begin{array}{l}0.1 \mathrm{~mol} / \mathrm{dm}^{3} \mathrm{TBAClO}_{4}+ \\
0.002 \mathrm{~mol} / \mathrm{dm}^{3} \text { monomeric } \\
\mathrm{LMnCl}_{2} \text {, } \\
\text { After deposition the film } \\
\text { was dried at room } \\
\text { temperature. }\end{array}$ & ITO & $\mathrm{Pt}$ & $\begin{array}{l}\mathrm{Ag} / \\
\mathrm{AgCl}\end{array}$ & -1.2 and $1.5 \mathrm{~V}$ & - & $\begin{array}{l}\text { Room } \\
\text { temp }\end{array}$ & 2 & $\begin{array}{l}1 \mathrm{~mol} / \mathrm{dm}^{3} \mathrm{~K} \\
\mathrm{Cl}\end{array}$ & $\begin{array}{l}\text { Film was homogeneously deposited with } \\
12 \mu \mathrm{m} \text { thick. The binding energy for the } \\
\text { film lies within the range of } 1-2 \\
\text { eV.Increase in conductivity may be } \\
\text { because of addition of ca. } 19 \mathrm{wt} \% \\
\text { carbon. }\end{array}$ & 144 & 139 \\
\hline 6 & $\begin{array}{l}0.1 \mathrm{M} \text { manganese acetate } \\
\text { After deposition the film } \\
\text { was annealed at } 150^{\circ} \mathrm{C} \text { for } \\
2 \mathrm{~h} \text {. }\end{array}$ & $\mathrm{AC}$ & - & $\begin{array}{l}\mathrm{Ag} / \\
\mathrm{AgCl}\end{array}$ & $0.90 \mathrm{~V}$ & $\begin{array}{l}120 \\
\mathrm{sec}\end{array}$ & $25^{\circ} \mathrm{C}$ & - & - & $\begin{array}{l}\text { The formation of } \mathrm{MnO}_{2} \text { with thickness } \\
\text { of the film was about } 0.58 \sim 1.25 \mu \mathrm{m} \text {. } \\
\text { The specific surface area of as -prepared } \\
\text { sample was } 7.7 \mathrm{~m}^{2} / \mathrm{g} \text {. Film was stable up } \\
\text { to } 2000 \text { charge discharge cycles. }\end{array}$ & 485.4 & 140 \\
\hline
\end{tabular}




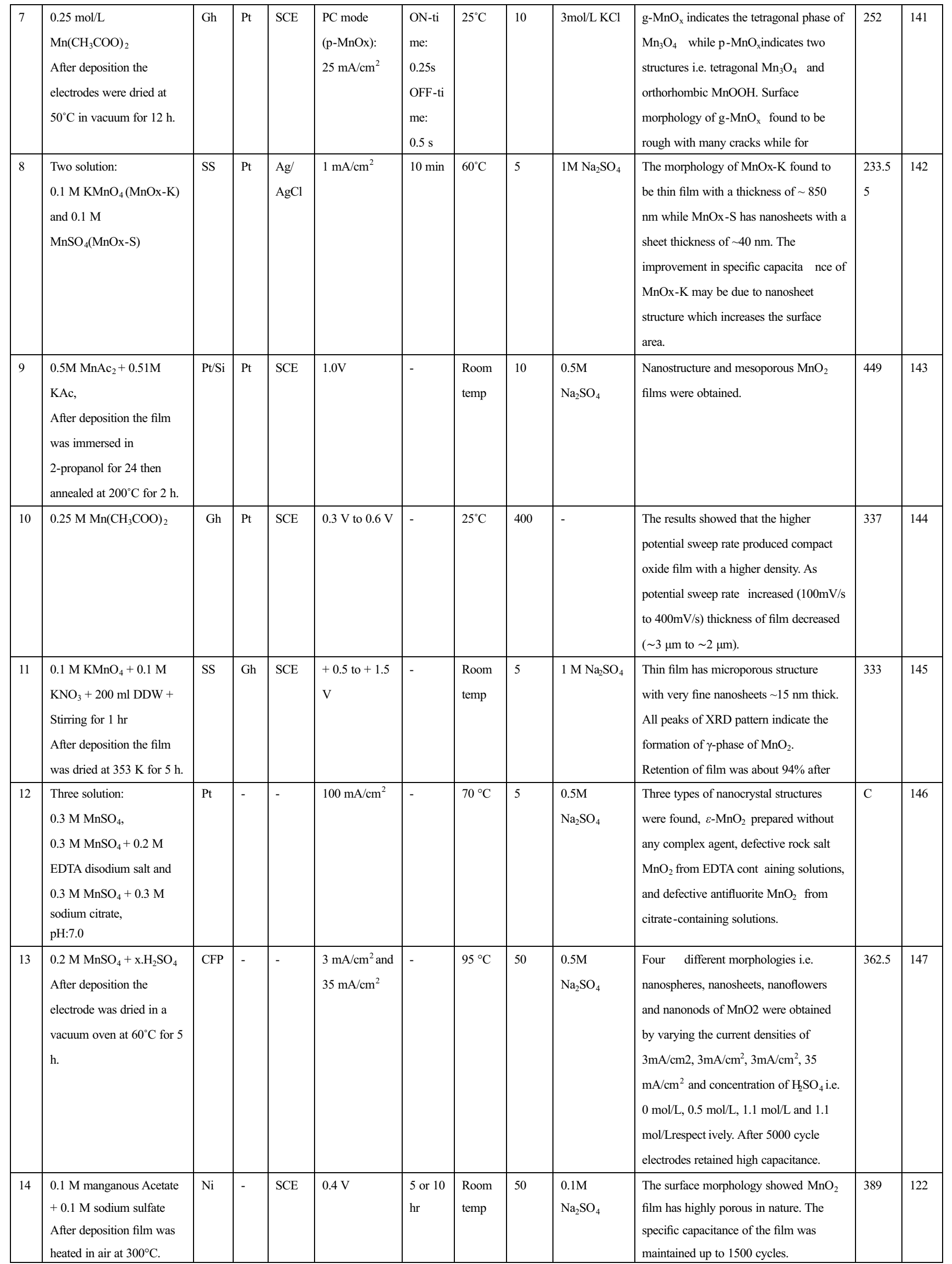




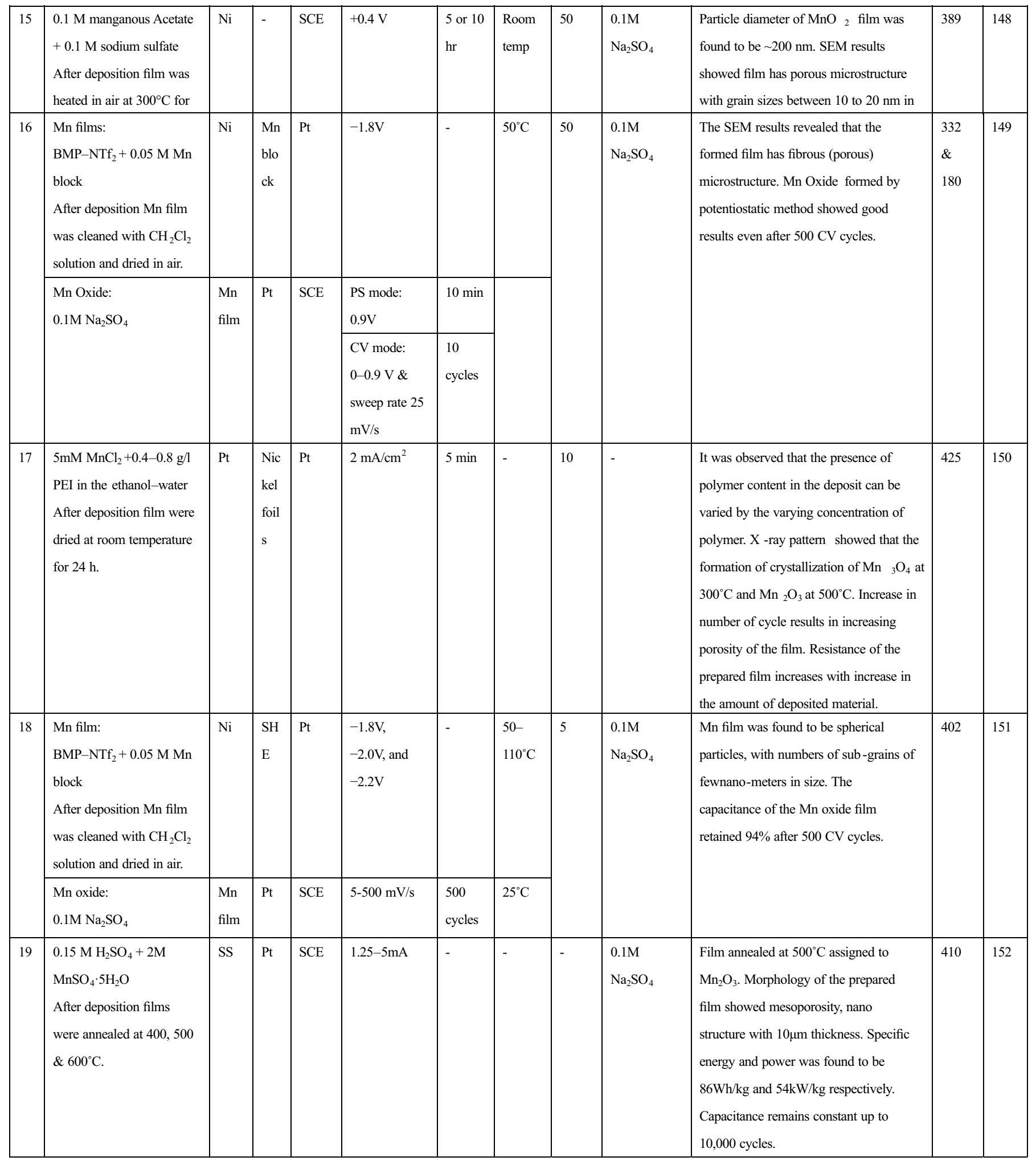




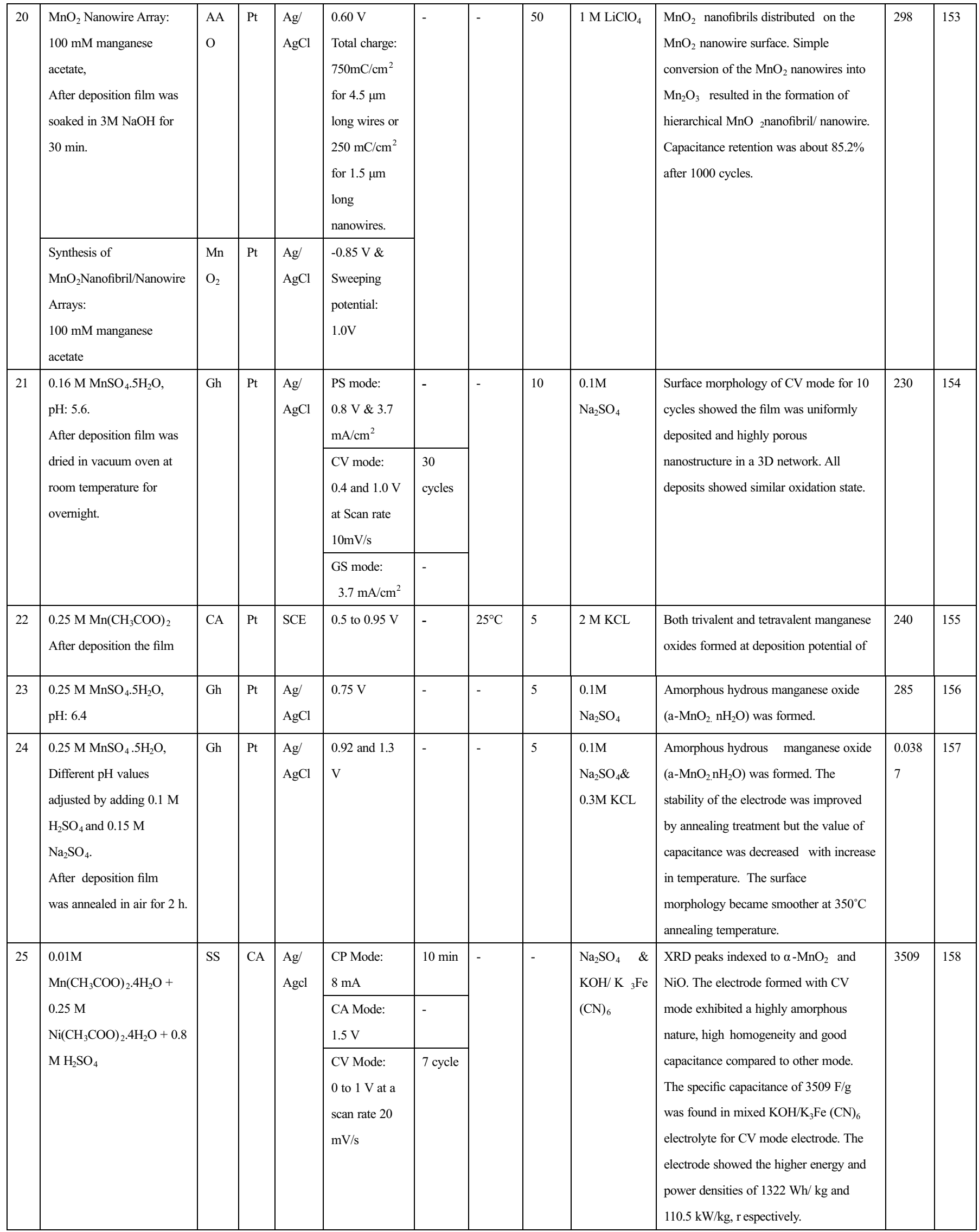




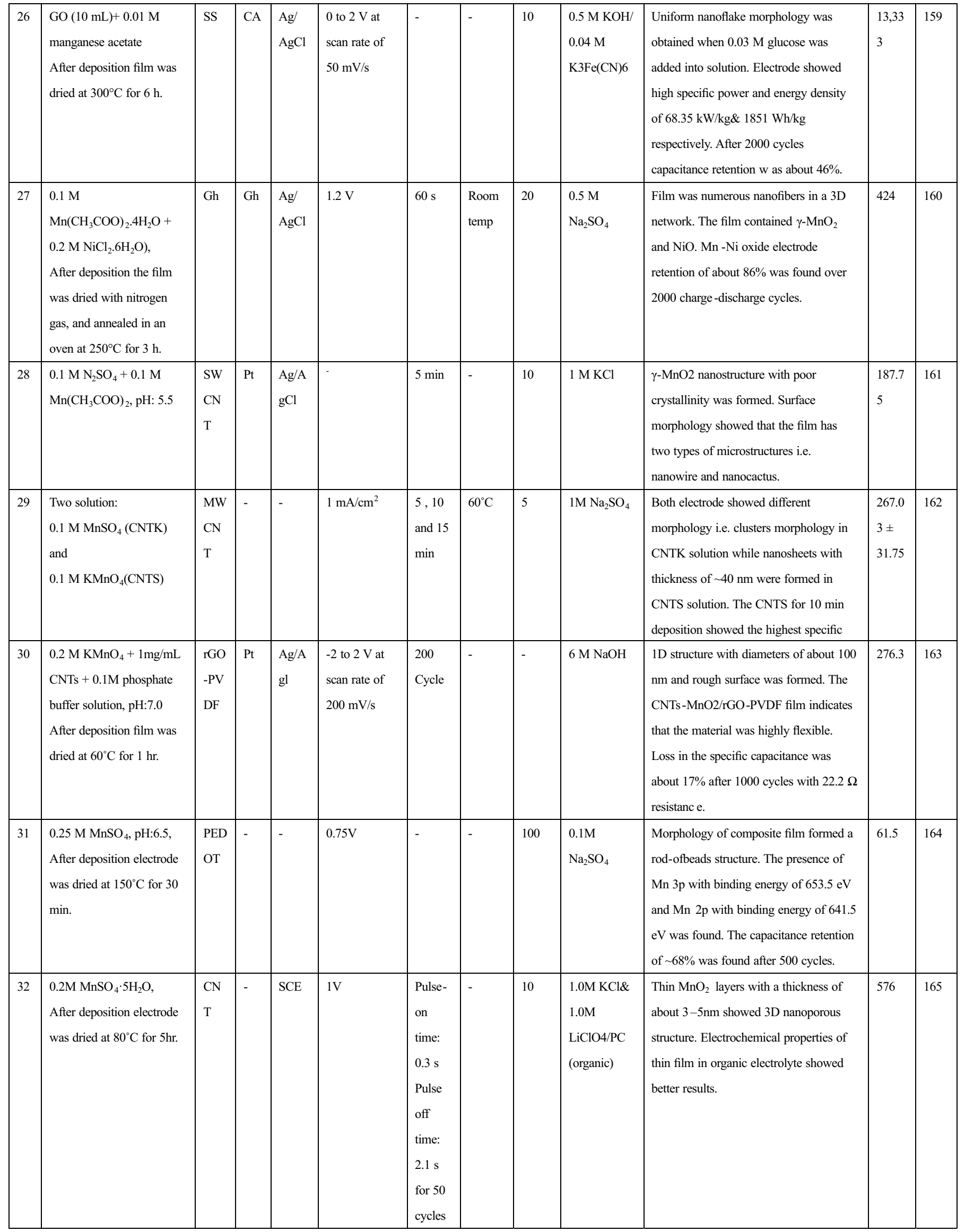




\begin{tabular}{|c|c|c|c|c|c|c|c|c|c|c|c|c|}
\hline 33 & $\begin{array}{l}0.16 \mathrm{M} \mathrm{MnSO}_{4} \cdot 5 \mathrm{H}_{2} \mathrm{O} \text {, } \\
\mathrm{pH}: 5.6 \\
\text { After deposition film was } \\
\text { dried in vacuum at room } \\
\text { temperature for } 24 \mathrm{hr} \text {. }\end{array}$ & $\begin{array}{l}\mathrm{CN} \\
\mathrm{Ts} / \\
\mathrm{Ni}\end{array}$ & $\mathrm{Pt}$ & SCE & $0.4 \mathrm{~V}$ & $3 \mathrm{~min}$ & $25^{\circ} \mathrm{C}$ & 5 & $\begin{array}{l}0.1 \mathrm{M} \\
\mathrm{Na}_{2} \mathrm{SO}_{4}\end{array}$ & $\begin{array}{l}10-25 \mathrm{~nm} \text { amorphous } \\
\mathrm{MnO} x \text { nanoparticles formed on the } \\
\mathrm{CNTs} / \mathrm{Ni} \text { substrate. The surface area of } \\
6.0 \mathrm{~m}^{2} / \mathrm{g} \text { for } \mathrm{MnO} x / \mathrm{Ni} \text { and } 20.2 \mathrm{~m}^{2} / \mathrm{g} \text { for } \\
\mathrm{MnO} x / \mathrm{CNTs} / \mathrm{Ni} \text { substrate was found. } \\
\text { The capacitance retention was about } \\
\sim 79 \% \text { over } 1000 \text { cycles. }\end{array}$ & 415 & 166 \\
\hline 34 & $\begin{array}{l}0.01 \mathrm{M} \mathrm{MnCl}_{2} \cdot 4 \mathrm{H}_{2} \mathrm{O}+ \\
0.02 \mathrm{M} \mathrm{Co}\left(\mathrm{NO}_{3}\right)_{2} \cdot 4 \mathrm{H}_{2} \mathrm{O}+ \\
0.01 \mathrm{M} \mathrm{KCl}, \\
\text { After deposition film was } \\
\text { annealing at } 500^{\circ} \mathrm{C} \text { for } 6 \mathrm{~h} .\end{array}$ & ITO & $\mathrm{Pt}$ & $\begin{array}{l}\mathrm{Ag} / \mathrm{A} \\
\mathrm{gCl}\end{array}$ & $-1.1 \mathrm{~V}$ & $\begin{array}{l}60 \mathrm{~s} \\
120 \mathrm{~s} \\
\text { and } \\
180 \mathrm{~s}\end{array}$ & $70^{\circ} \mathrm{C}$. & 1 & $2 \mathrm{M} \mathrm{KOH}$ & $\begin{array}{l}\text { The MCO nanosheets were compact } \\
\text { with homogeneous shape and uniformly } \\
\text { grown with 3D structures of thicknesses } \\
\text { in the range of } 10-40 \mathrm{~nm} \& \text { length } \sim 1-2 \\
\mu \mathrm{m} \text {. Formation of } \mathrm{MnCo}_{2} \mathrm{O}_{4} \text { with an } \\
\text { atomic ratio of } \sim 1: 2 \text { for } \mathrm{Mn} \text { and Co. } \\
\text { electrode showed good cyclic stability } \\
\text { after } 1000 \mathrm{CV} \text { cycles. }\end{array}$ & 290 & 167 \\
\hline 35 & $\begin{array}{l}\mathrm{MnO} 2 \text { : } \\
0.1 \mathrm{M} \mathrm{MnSO}_{4} \cdot 4 \mathrm{H}_{2} \mathrm{O}+0.1 \\
\mathrm{M} \text { citric acid, } \mathrm{pH} \sim 10.5 \text { by } \\
\text { adding } \mathrm{NaOH} \text {. } \\
{\mathrm{Fe}: \mathrm{MnO}_{2}:} \text { : } \\
0.5,1,2 \text { and } 4 \text { at } \% \text { of } \\
\text { ferric sulfate. }\end{array}$ & SS & Gh & SCE & $5 \mathrm{~mA} / \mathrm{cm}^{2}$ & - & $\begin{array}{l}\text { Room } \\
\text { temp }\end{array}$ & 5 & $1 \mathrm{M} \mathrm{Na}_{2} \mathrm{SO}_{4}$ & $\begin{array}{l}\text { The value of capacitance decreases with } \\
\text { increase in scan rate. Maximum specific } \\
\text { capacitance achieved for } 2 \text { at } \% \\
\text { Fe: } \mathrm{MnO}_{2} \text {. Due to the } \mathrm{Fe} \text { addition } \\
\text { specific energy and specific power } \\
\text { increased from } 1.2 \text { to } 1.6 \mathrm{Wh} / \mathrm{kg} \text { and } \\
0.4-103 \text { to } 0.5-103 \mathrm{~W} / \mathrm{kg} \text { respectively. } \\
\text { Supercapacitive performance of } \mathrm{MnO} \\
\text { thin film s improved due to addition of } \\
\text { Fe. }\end{array}$ & 218 & 168 \\
\hline 36 & $\begin{array}{l}\text { Mn oxide deposition: } \\
0.01 \mathrm{M} \mathrm{Mn}\left(\mathrm{C}_{2} \mathrm{H}_{3} \mathrm{O}_{2}\right)+ \\
0.02 \mathrm{M} \mathrm{NH}_{4}\left(\mathrm{C}_{2} \mathrm{H}_{3} \mathrm{O}_{2}\right)+ \\
10 \% \mathrm{C}_{2} \mathrm{H}_{6} \mathrm{OS}, \\
\text { After deposition the } \\
\text { samples were dried in air } \\
\text { at } 100^{\circ} \mathrm{C} \text { for } 60 \text { min. }\end{array}$ & $\begin{array}{l}\mathrm{Ni} \\
\text { foa } \\
\mathrm{m}\end{array}$ & $\mathrm{Pt}$ & - & $5-25 \mathrm{~mA} / \mathrm{cm}^{2}$ & $\begin{array}{l}2.5-10 \\
\min \end{array}$ & $60^{\circ} \mathrm{C}$ & 5 & $\begin{array}{l}0.5 \mathrm{M} \\
\mathrm{Na}_{2} \mathrm{SO}_{4}\end{array}$ & $\begin{array}{l}\text { The film was poorly crystalline with } \\
\text { grain size } \sim 5 \mathrm{~nm} \text {, it could be indexed to } \\
\text { either a hexagonal structure }\left(\mathrm{MnO}_{2}\right) \text { or } \\
\text { cubic spinel structure }\left(\mathrm{Mn}_{3} \mathrm{O}_{4}\right) \text {. Addition } \\
\text { of PEDOT cause to increased the } \\
\text { specific capacitance from } 120 \text { to } 159 \mathrm{~F} / \mathrm{g} \text {. } \\
\text { The capacitance value slightly decr eased }\end{array}$ & $\begin{array}{l}159 \\
\& \\
120\end{array}$ & 169 \\
\hline & $\begin{array}{l}\text { PEDOT deposition: } \\
0.08 \mathrm{M} \text { EDOT }+0.2 \mathrm{M} \\
\mathrm{LiF}_{4} \mathrm{~B}+0.14 \mathrm{M} \text { sodium } \\
\text { dodecyl sulfate }\end{array}$ & $\begin{array}{l}\text { Mn } \\
\text { Oxi } \\
\text { de } \\
\text { film }\end{array}$ & $\mathrm{Pt}$ & SCE & $1 \mathrm{~V}$ & $45 \mathrm{~s}$ & $25^{\circ} \mathrm{C}$ & & & after 2000 cycles. & & \\
\hline 37 & $\begin{array}{l}0.1 \mathrm{M} \mathrm{Mn}\left(\mathrm{CH}_{3} \mathrm{COO}\right)_{2}+ \\
0.1 \mathrm{M} \mathrm{Na}_{2} \mathrm{SO}_{4} . \\
\text { After deposition films } \\
\text { were dried and annealed in } \\
\text { air at } 300^{\circ} \mathrm{C} \text { for } 2 \mathrm{~h} .\end{array}$ & $\begin{array}{l}\mathrm{Ni} \\
\text { foa } \\
\mathrm{m}\end{array}$ & $\mathrm{Pt}$ & SCE & $\begin{array}{l}\text { PD mode: } \\
+0.3 \text { to }+0.6 \\
\mathrm{~V} \text { at scan rate: } \\
25 \mathrm{mV} / \mathrm{s} \\
\mathrm{PS} \text { mode: } \\
+0.6 \mathrm{~V} \\
\mathrm{PS}+\mathrm{PD} \text { mode: } \\
+0.6 \mathrm{~V} \& \\
(+0.3 \text { and } \\
+0.6 \mathrm{~V}) \text { at a } \\
\mathrm{scan} \text { rate } 25 \\
\mathrm{mV} / \mathrm{s}\end{array}$ & $\begin{array}{l}900 \mathrm{~s} \\
\& 800 \\
\text { cycles }\end{array}$ & $\begin{array}{l}\text { Room } \\
\text { temp }\end{array}$ & 5 & $9 \mathrm{M} \mathrm{LiNO}_{3}$ & $\begin{array}{l}\text { All electrodes indexed to pyrolusite } \\
\mathrm{MnO}_{2} . \mathrm{PS}+\mathrm{PD} \text { mode showed higher } \\
\text { pore volume, pore size \& higher specific } \\
\text { capacitance }(325 \mathrm{~F} / \mathrm{g}) \text {, than those of PD } \\
(200 \mathrm{~F} / \mathrm{g} \text { ) and } \mathrm{PS} \text { mode }(175 \mathrm{~F} / \mathrm{g}) \text {. The } \\
\text { energy and power density of PS + PD } \\
\text { mode electrode was found to be } 7.66 \\
\text { Wh } / \mathrm{kg} \& 600 \mathrm{~W} / \mathrm{kg} \text { respectively. The } \\
\text { retention of capacitance was } 98 \% \text { over } \\
10,000 \text { cycles. }\end{array}$ & 325 & 170 \\
\hline
\end{tabular}


Table 4 Electrochemical deposition of Nickel oxide/hydroxide and their composition.

\begin{tabular}{|c|c|c|c|c|c|c|c|c|c|c|c|c|}
\hline \multirow{2}{*}{$\begin{array}{l}\text { Sr. } \\
\text { No }\end{array}$} & \multirow{2}{*}{$\begin{array}{c}\text { Chemical/Bath } \\
\text { Composition \& conditions }\end{array}$} & \multicolumn{3}{|c|}{ Substrate Electrode } & \multicolumn{5}{|c|}{ Details } & \multirow[t]{2}{*}{ Remarks/Properties } & \multirow{2}{*}{$\begin{array}{c}\mathrm{SC} \\
(\mathrm{F} / \mathrm{g})\end{array}$} & \multirow[t]{2}{*}{ Ref. } \\
\hline & & A & K & $\mathrm{R}$ & $\begin{array}{l}\text { Applied } \\
\text { Current/Volt } \\
\text { age }\end{array}$ & $\begin{array}{l}\text { Depo. } \\
\text { time }\end{array}$ & Temp. & $\begin{array}{l}\text { Scan } \\
\text { Rate } \\
(\mathrm{mV} / \mathrm{s})\end{array}$ & Electrolyte & & & \\
\hline 1 & $\begin{array}{l}0.08 \mathrm{M} \mathrm{Ni}\left(\mathrm{NO}_{3}\right)_{2}, \\
\text { After deposition film was } \\
\text { thermal treated at in air at } \\
250^{\circ} \mathrm{C} \text { (temp rate: } \\
5^{\circ} \mathrm{C} / \mathrm{min} \text { ) in muffle stove } \\
\text { for } 2 \mathrm{~h} \text {. }\end{array}$ & $\mathrm{Ni}$ & $\mathrm{Pt}$ & SCE & $-0.90 \mathrm{~V}$ & - & & 40 & $1 \mathrm{M} \mathrm{KOH}$ & $\begin{array}{l}\text { Formation of } \alpha \text { - nickel hydroxides with } \\
\text { the grain size of } 3.48 \mathrm{~nm} \text {. The capacitance } \\
\text { maintained up to } 87 \% \text { of maximum } \\
\text { capacity after } 500 \text { cycles }\end{array}$ & 1478 & 180 \\
\hline 2 & $\begin{array}{l}0.13 \mathrm{M} \text { sodium acetate }+ \\
0.13 \mathrm{M} \text { nickel sulfate }+ \\
0.1 \mathrm{M} \text { sodium sulfate. } \\
\text { After deposition film was } \\
\text { dried at } 300^{\circ} \mathrm{C} \text { in air for } 1 \\
\mathrm{~h} \text {. }\end{array}$ & SS & $\mathrm{Pt}$ & $\begin{array}{l}\mathrm{Ag} / \\
\mathrm{AgCl}\end{array}$ & $0.5 \mathrm{~mA} / \mathrm{cm}^{2}$ & $60 \mathrm{~min}$ & $\begin{array}{l}\text { Room } \\
\text { temp }\end{array}$ & 25 & $1 \mathrm{M} \mathrm{KOH}$ & $\begin{array}{l}\text { Film exhibits highly porous morphology } \\
\text { with nanoflakes like structure of thickness } \\
12-16 \mathrm{~nm} \text {. XRD pattern indicates that the } \\
\text { formation of } \mathrm{NiO} \text { with poor crystallinity. } \\
87.5 \% \text { retention of capacitance after } 5000 \\
\text { cycles. }\end{array}$ & 167.3 & 181 \\
\hline 3 & $\begin{array}{l}\text { Three solution: } \\
\mathrm{NiCl}_{2} \cdot 6 \mathrm{H}_{2} \mathrm{O}(\mathrm{NiO}-\mathrm{C}) \text {, } \\
\mathrm{Ni}\left(\mathrm{NO}_{3}\right)_{2} \cdot 6 \mathrm{H}_{2} \mathrm{O}(\mathrm{NiO}-\mathrm{N}) \\
\text { and } \mathrm{NiSO}_{4} \cdot 6 \mathrm{H}_{2} \mathrm{O}(\mathrm{NiO}-\mathrm{S}) \text {, } \\
\text { After deposition films } \\
\text { were annealed in air at } \\
500^{\circ} \mathrm{C} \text { for } 2 \mathrm{~h} \text {. }\end{array}$ & SS & Gh & SCE & $\begin{array}{l}\mathrm{NiO}-\mathrm{C} \text { : } \\
-0.75 \text { to }-0.6 \\
\mathrm{~V} \\
\mathrm{NiO}-\mathrm{N}: \\
-0.7 \text { to }-0.55 \\
\mathrm{~V} \\
\mathrm{NiO}-\mathrm{S}: \\
-0.8 \text { to }-0.65\end{array}$ & $30 \mathrm{~min}$ & $\begin{array}{l}\text { Room } \\
\text { temp }\end{array}$ & 5 & $1 \mathrm{M} \mathrm{KOH}$ & $\begin{array}{l}\text { All electrodes showed the cubic phase of } \\
\text { NiO. It was observed that the growth of } \\
\text { nanoflakes uniformly distributed on the } \\
\text { surface. NiO-S electrodes showed all } \\
\text { over good performance i.e. high } \\
\text { capacitance, low impedance } 1.27 \Omega / \mathrm{cm} \\
\text { and high surface area } 91.5 \mathrm{~m}^{2} / \mathrm{g} \text { with } \\
\text { better stability }(85.6 \%) .\end{array}$ & 893 & 182 \\
\hline 4 & $\begin{array}{l}0.1 \mathrm{M} \mathrm{Ni}\left(\mathrm{NO}_{3}\right)_{2} \text {, } \\
\text { After deposition film were } \\
\text { annealed at } 573 \mathrm{~K} \text { for } 90 \\
\text { min. }\end{array}$ & SS & $\mathrm{Gh}$ & SCE & $\begin{array}{l}0 \text { to }-1.2 \mathrm{~V} \text { at } \\
\text { scan } \\
\text { rate: } 50 \mathrm{mV} / \mathrm{s}\end{array}$ & $\begin{array}{l}30 \\
\text { cycles }\end{array}$ & - & 100 & $1 \mathrm{M} \mathrm{KOH}$ & $\begin{array}{l}\text { Formed NiOnanoflakes thin film showed } \\
\text { specific power of } 1.0 \mathrm{~kW} / \mathrm{kg} \text { and energy } \\
14.6 \mathrm{Wh} / \mathrm{kg} \text {. Impedance of prepared film } \\
\text { was } 1.34 \Omega \text { and cyclic stability up to } 94 \% \\
\text { over } 1000 \text { cycles }\end{array}$ & 222 & 183 \\
\hline 5 & $0.08 \mathrm{M} \mathrm{Ni}\left(\mathrm{NO}_{3}\right)_{2} \cdot 6 \mathrm{H}_{2} \mathrm{O}$ & $\mathrm{Ni}$ & $\mathrm{Pt}$ & $\begin{array}{l}\mathrm{Ag} / \\
\mathrm{AgCl}\end{array}$ & $-0.90 \mathrm{~V}$ & - & $\begin{array}{l}\text { Room } \\
\text { temp }\end{array}$ & - & $1 \mathrm{M} \mathrm{KOH}$ & $\begin{array}{l}\alpha-\mathrm{Ni}(\mathrm{OH})_{2} \text { showed particle like } \\
\text { morphology with a loosely packed } \\
\text { structure. }\end{array}$ & 2595 & 184 \\
\hline 6 & $\begin{array}{l}3 \mathrm{mM} \mathrm{Ni}\left(\mathrm{NO}_{3}\right)_{2} \cdot 6 \mathrm{H}_{2} \mathrm{O}+3 \\
\mathrm{mM} \mathrm{Fe}\left(\mathrm{NO}_{3}\right)_{3} \cdot 9 \mathrm{H}_{2} \mathrm{O}\end{array}$ & $\mathrm{NF}$ & $\mathrm{Pt}$ & $\begin{array}{l}\mathrm{Ag} / \\
\mathrm{AgCl}\end{array}$ & $-1.0 \mathrm{~V}$ & $300 \mathrm{~s}$ & $10^{\circ} \mathrm{C}$ & 5 & $1 \mathrm{M} \mathrm{KOH}$ & $\begin{array}{l}\text { The formation of interconnected } \\
\text { mesoporous structures with the pore size } \\
\text { of } 50 \mathrm{~nm} \text {. }\end{array}$ & - & 185 \\
\hline
\end{tabular}

\section{List of Abbreviates:}

\section{Pt: Platinum}

Gh: Graphite

SS: Stainless steel

ITO: Indium doped tin oxide

SHE: Standard hydrogen electrode.

SCE: Saturated calomel electrode

Ti: Titanium

$\mathrm{TiO}_{2}$ : Titanium oxide

AAO: Anodic Aluminum oxide

Ni: Nickel

AC: Activated Carbon

Si: Silicon

Mn: Manganese

$\mathrm{Cu}$ : Copper

CFP: Carbon fiber paper

CNT: Carbon nanotube
SWCNT: Single walled Carbon nanotube MWCNT: multiwalled Carbon nanotube

$\mathrm{CdO}$ : Cadmium oxide

NF: Nickel Foam

rGO: Reduced graphene oxide

PVDF: Polyvinylidene fluoride

ED: Electrodeposition

SC: Specific Capacitance

PD mode: Potentiodynamic mode

PS mode: Potentiostatic mode

PC mode: Pulse Current deposition mode

GS mode: Galvanostatic mode

CP mode: Galvanostatic (chronopotentiometry) mode

CV mode: Cyclic voltammetry mode

CA mode: Potentiostatic (chronoamperometry) mode

CV: Cyclic-Voltametry. 
Table 5 Electrochemical deposition of Cobalt oxide/hydroxide and their composition.

\begin{tabular}{|c|c|c|c|c|c|c|c|c|c|c|c|c|}
\hline \multirow{2}{*}{$\begin{array}{l}\text { Sr. } \\
\text { No }\end{array}$} & \multirow{2}{*}{$\begin{array}{c}\text { Chemical/Bath } \\
\text { Composition \& condition }\end{array}$} & \multicolumn{3}{|c|}{ Substrate Electrode } & \multicolumn{5}{|c|}{ Details } & \multirow[t]{2}{*}{ Remarks/Properties } & \multirow{2}{*}{$\begin{array}{l}\mathrm{SC} \\
(\mathrm{F} / \mathrm{g})\end{array}$} & \multirow[t]{2}{*}{ Ref. } \\
\hline & & A & K & $\mathrm{R}$ & $\begin{array}{c}\text { Applied } \\
\text { Current/Volt } \\
\text { age }\end{array}$ & $\begin{array}{l}\text { Depo. } \\
\text { time }\end{array}$ & Temp. & $\begin{array}{l}\text { Scan } \\
\text { Rate } \\
\mathrm{mV} / \mathrm{s}\end{array}$ & Electrolyte & & & \\
\hline 1 & $\begin{array}{l}0.05 \mathrm{M} \text { cobalt chloride, } \\
\text { pH: } \sim 10 \text { by adding } 30 \% \\
\text { ammonia. }\end{array}$ & $\mathrm{Cu}$ & $\begin{array}{l}\mathrm{Pt} \\
\text { coa } \\
\text { ted } \\
\mathrm{Ti}\end{array}$ & $\begin{array}{l}\mathrm{Ag} / \\
\mathrm{AgCl}\end{array}$ & $-1.2 \mathrm{~V}$ & $15 \mathrm{~min}$ & - & 20 & $2 \mathrm{M} \mathrm{KOH}$ & $\begin{array}{l}\text { Formation of } \mathrm{Co}_{3} \mathrm{O}_{4} \text { film with } \\
\text { nanocrystalline structure. Film was } \\
\text { highly porous with thickness of } 0.60 \\
\mathrm{mg} / \mathrm{cm}^{2} \text {. The specific power and } \\
\text { energy of the electrode were } 1.33 \\
\mathrm{~kW} / \mathrm{kg} \text { and } 4.0 \mathrm{Wh} / \mathrm{kg} \text { respectively. }\end{array}$ & 235 & 197 \\
\hline 2 & $\begin{array}{l}0.1 \mathrm{M} \mathrm{Co}\left(\mathrm{NO}_{3}\right)_{2} \cdot 6 \mathrm{H}_{2} \mathrm{O} \\
\text { After deposition film was } \\
\text { dried in vacuum oven at } \\
200^{\circ} \mathrm{C} \text { for } 2 \mathrm{~h}\end{array}$ & $\begin{array}{l}\mathrm{CA} \\
\text { foa } \\
\mathrm{m}\end{array}$ & $\mathrm{Pt}$ & $\begin{array}{l}\mathrm{Ag} / \\
\mathrm{AgCl}\end{array}$ & $-0.8 \mathrm{~V}$ & $20 \min$ & $70^{\circ} \mathrm{C}$ & 500 & $1 \mathrm{M} \mathrm{NaOH}$ & $\begin{array}{l}\text { All peaks were indexed to cubic } \\
\text { lattice of } \mathrm{Co}_{3} \mathrm{O}_{4} \text {.SEM \& TEM showed } \\
\text { that the formation multilayers with } \\
\text { sheet like structure of } \mathrm{Co}_{3} \mathrm{O}_{4} \text {. }\end{array}$ & 106 & 198 \\
\hline \multirow[t]{3}{*}{3} & \multirow[t]{3}{*}{$\begin{array}{l}0.05 \mathrm{M} \mathrm{Co}\left(\mathrm{NO}_{3}\right)_{2} \\
\text { After deposition film was } \\
\text { air annealed at } 623 \mathrm{~K} \text { for } \\
180 \mathrm{~min}\end{array}$} & \multirow[t]{3}{*}{ SS } & \multirow[t]{3}{*}{ Gh } & \multirow[t]{3}{*}{ SCE } & $\begin{array}{l}\text { PD mode: } \\
0 \text { to }-1.2 \mathrm{~V} \text { at } \\
\text { scan rate: } 50 \\
\mathrm{mV} / \mathrm{s}\end{array}$ & - & & 100 & $1 \mathrm{M} \mathrm{KOH}$ & \multirow{3}{*}{$\begin{array}{l}\text { Formation of cubic crystal structure of } \\
\mathrm{Co}_{3} \mathrm{O}_{4} \text {.Morphology of the film shows } \\
\text { the porous with nanoflakes-like } \\
\text { structure. PS electrode showed energy } \\
\text { and power density of } 19 \mathrm{Wh} / \mathrm{kg} \text { and } \\
3.8 \mathrm{~kW} / \mathrm{kg} \text { respectively. }\end{array}$} & \multirow[t]{3}{*}{248} & \multirow[t]{3}{*}{199} \\
\hline & & & & & $\begin{array}{l}\text { PS mode: } \\
-0.9 \mathrm{~V}\end{array}$ & $5 \mathrm{~min}$ & & & & & & \\
\hline & & & & & $\begin{array}{l}\text { GS mode: } \\
3 \mathrm{~mA} / \mathrm{cm}^{2}\end{array}$ & - & & & & & & \\
\hline 4 & $\begin{array}{l}1.189 \mathrm{gr} \mathrm{CoCl}_{2} \cdot 6 \mathrm{H}_{2} \mathrm{O}+1 \\
\text { gr C }_{12} \mathrm{H}_{22} \mathrm{O}_{11} \text { were } \\
\text { dissolved in } 1 \text { litter water. }\end{array}$ & SS & $\mathrm{Gh}$ & $\mathrm{Gh}$ & $10 \mathrm{~mA} / \mathrm{cm}^{2}$ & $30 \mathrm{~min}$ & $40^{\circ} \mathrm{C}$ & 5 & $1 \mathrm{M} \mathrm{KOH}$ & $\begin{array}{l}\text { The formation of hexagonal } \\
\text { brucite-like structure of } \beta-\mathrm{Co}(\mathrm{OH})_{2} \\
\text { phase. SEM and TEM showed that the }\end{array}$ & $\begin{array}{l}1288 . \\
1\end{array}$ & 200 \\
\hline 5 & $\begin{array}{l}0.1 \mathrm{M} \mathrm{Co}\left(\mathrm{NO}_{3}\right) 2.6 \mathrm{H}_{2} \mathrm{O}+ \\
\mathrm{Na}_{2} \mathrm{SO}_{3} \text { in 1:1 volumetric } \\
\text { ratio }\end{array}$ & $\mathrm{CdO}$ & $\mathrm{Pt}$ & $\begin{array}{l}\mathrm{Ag} / \\
\mathrm{AgCl}\end{array}$ & $4 \mathrm{~mA}$ & $\begin{array}{l}300 \\
\mathrm{sec}\end{array}$ & $\begin{array}{l}\text { Room } \\
\text { temp }\end{array}$ & 10 & $1 \mathrm{M} \mathrm{KOH}$ & $\begin{array}{l}\text { All XRD peaks were matched with } \\
\mathrm{Co}(\mathrm{OH})_{2} . \text { The capacitance retention } \\
\text { was about } 54 \% \text { after } 1000 \text { cycles. } \\
\text { Electrode showed high energy and } \\
\text { power density of } 98.83 \mathrm{Wh} / \mathrm{kg} \text { and } \\
0.75 \mathrm{~kW} / \mathrm{kg} \text { respectively. }\end{array}$ & 1119 & 201 \\
\hline
\end{tabular}

\section{Acknowledgement}

The authors are thankful to Indian Space Research OrganizationSavitribai Phule Pune University Space Technology Cell, SPPU, Pune for financial support.

\section{References}

1. G. Wang, L. Zhang and J. Zhang, Chem. Soc. Rev., 2012, 41, 797-828.

2. A. Gonzalez, E. Goikole, J. A. Barrena and R. Mysyk, Ren. Susta. Energy Rev., 2016, 58, 1189-1206.

3. A. Burke, J. Power Sources, 2000, 91, 37-50.

4. J. Miller, Battery \& Energy Storage Technology, Best Magazine Autumn 2007, 61-78.

5. R. Kotz, S. Muller, M. Bartschi, B. Schnyder, P. Dietrich, F. N. Buchi, A. Tsukada, G. G. Scherer, P. Rodatz, O. Garcia, P. Barrade, V. Hermann and R. Gallay, Electrochem. Soc. Proc., 2001, 21, 564.

6. J. R. Miller and P. Simon, Mater. Sci., 2008, 321651.

7. N. L. Wu, Mater. Chem. Phys., 2002, 75, 6.

8. Y. M. Cai, Z. Y. Qin and L. Chen, Progress Nat. Sci: Mater. Int., 2011, 21, 460.

9. L. L. Zhang and X. S. Zhao, Chem. Soc. Rev., 2009, 38, 2520.
10. A. K. Mittal and M. J. Kumar, Nanosci. Nanotech., 2011,13, 263.

11. B. E. Conway, Plenum Press, New York, 1999, 222.

12. A. S. Arico, P. Bruce, B. Scrosati, J. M. Tarascon and W. V. Schalkwijk, Nature Mater., 2005, 4, 366.

13. E. Frackowiak, Phys. Chem. Chem. Phys., 2007, 9, 1774.

14. H. Pan, J. Li and Y. Feng, Nanoscale Res. Lett., 2010, 5, 654.

15. M. Inagaki, H. Konno and O. Tanaike, J. Power Sources, 2010, 195, 7880.

16. E. Frackowiak and F. Beguin, Carbon, 2001, 39, 937.

17. A. G. Pandolfo and A. Hollenkamp, J. Power Sources, 2006, 157, 11.

18. P. Simon and A. Burke, Interface, 2008, 17, 38.

19. S. W. Zhang and G. Z. Chen, Energy Mater, 2008, 3, 186.

20. M. Winter and R. J. Brodd, Chem. Rev., 2004, 104, 4245.

21. M. H. Ervina, B. S. Miller, B. Hanrahan, B. Mailly and T. Palacios, Electrochim. Acta, 2012, 65, 37.

22. M.A. Pope, S. Korkut, C. Punckt and I. A. Aksay, J. Electrochem. Soc., 2013, 160, A1653.

23. M. F. Garcia and J. A. Rodriguez, Nanomaterials: Inorganic and Bioinorganic Perspectives, 2007

24. M. J. lakshmi and K. B. Subramanian, Int. J. Electrochem. Sci., 2008, 3, $1196-1217$.

25. J. M. Tarascon and M. Armand, Nature, 2001, 414, 359-367. 
26. M. S. Whittingham, Chem. Rev. 2004, 104, 4271-4301.

27. T. Brezesinski, J. Wang, S. H. Tolbert and B. Dunn, Nat. Mater., 2010, 9, 146-151.

28. V. Subramanian, S. C. Hall, P. H. Smith and B. Rambabu, Solid State Ionics, 2004, 175, 511-515.

29. L. Liu, Z. Niu and J. Chen,Chem. Soc. Rev., 2016, 45, 4340-4363

30. Y. Zhang, H. Feng, X. Wu, L.Wang, A. Zhang, T. Xia, H. Dong, X. Li and L. Zhang, Int. J. Hydrogen Energy, 2009, 34, 4889

31. M. D. Stoller, S. Park, Y. Zhu, J. An and R. S. Rouf, Nano lett., 2008, 8, 3498.

32. H. P. Wu, D. W. He, Y. S. Wang, M. Fu, Z. L. Liu, J. G. Wang and H. T. Wang, IEEE, 2010, 465.

33. B. Rajagopalan and J. S. Chung, Nanoscale Res. Lett., 2014, 9, 1.

34. C. D. Lokhande, D. P. Dubal and O. S. Joo, Curr. Appl. Phys., 2011, 11, $255-$ 270.

35. R. Kotz , M. Carlen, Electrochem. Acta, 2000, 45, 2483-2498.

36. P. Simon and Y. Gogotsi, Nat. Mater, 2008, 7.

37. S. M. Chen, R. Ramachandran, V. Mani and R. Saraswathi, Int. J. Electrochem. Sci., 2014, 9, $4072-4085$.

38. A. Shukla, Resonance, 2001, 6 (8), 72-81.

39. A. Schneuwly, R. Gallay, Proceedings PCIM, 2000, 1-10.

40. C. Meng, O. Z. Gall and P. P. Irazoqui, Biomed. Microdevices, 2013, 15, $973-$ 983.

41. X. Li and B. Wei, Nano Energy, 2013, 2, 159

42. M. S. Halper and J. C. Ellenbogen, The MITRE Corporation, McLean, Virginia, USA, 2006.

43. H. F. Li, R. D. Wang and R. Cao, Micropor. Mesopor. Mat., 2008, 111, 32-38.

44. S. Bose, T. Kuila, A. K. Mishra, R. Rajasekar, N. H. Kim and J. H. Lee, J. Mater. Chem., 2012, 22, 767-784.

45. L. L. Zhang, R. Zhou and X. S. Zhao, J. Mater. Chem., 2010, 20, 5983

46. T. Chen, H. Peng, M. Durstock and L. Dai, Sci. Rep. 2014, 4, 3612.

47. Y. Li, J. Dong, J. Zhang,X. Zhao, P. Yu, L. Jin and Q. Zhang, Small, 2015, 11.

48. K. Chen, Y. Yang, K. Li, Z. Ma, Y. Zhou and D. Xue, ACS Sustain. Chem. Eng., 2014, 2, 440-444.

49. R. Ramachandran, M. Saranya, V. Velmurugan, B. P. C. Ragupathy, S. K. Jeong and A. N. Grace, Appl. Energy, 2015, 153, 22- 31.

50. W. Chen, R. B. Rakhi and H. N. Alshareef, J. Phys. Chem. C, 2013, 117, 15009-15019.

51. Q. Du, M. Zheng, L. Zhang, Y. Wang, J. Chen, L. Xue, W.Dai, G. Ji and J. Cao, Electrochim. Acta, 2010, 55, 3897

52. H. Jiang, J. Ma and C. Z. Li, Adv. Mater., 2012, 24, 4197- 4202.

53. M. Q. Wu, J. H. Gao, S. R. Zhang and A. Chen, J. Porous Mater. 2006, 13, 407-412.

54. Y. Lin, N. Zhao, W. Nie and X. Ji, J. Phys. Chem. C, 2008, 112, 16219.

55. W. Sun and X. Chen, J. Power Sources, 2009, 193, 924.

56. M. Shao, Z. Li, R. Zhang, F. Ning, M. Wei, D. G. Evans and X. Duan, Small 2015, 11(29), 3530-3538

57. S. Nejati, T. E. Minford, Y. Y. Smolin, K. K. S. Lau, ACS Nano, 2014, 8, 5413-5422.

58. R. Ramachandran, M. Saranya, P. Kollu, B. P. C. Ragupathy, S. K. Jeong and A. N. Grace, Electrochim. Acta, 2015, 178, 647-657.

59. N. Terasawa and K. Asaka, Langmuir, 2014, 30, 14343-14351.

60. Y. Li, M. V. Zijll, S. Chiang and N. Pan, J. Power Sources, 2011, 196, 6003.

61. A. Burke, Electrochem. Acta, 2007, 53, 1083-1091.

62. Y. Lin, X. Wang, G. Qian and J. J. Watkins, Chem. Mater. 2014, 26, 2128-2137.

63. P. Simon and K. Naoi, Electrochem. Soc.interface, 2008, 34-38.

64. R. C. Ambare, R. S. Mane and B. J. Lokhande, Int. J. Adv. Res., 2016, 4(3), 1943-1975

65. R. S. Kate, S. A. Khalate, R. J. Deokate, J. Alloy. Compd., 2017

66. M. Rajkumar,C. T. Hsu, T. H. Wu, M. G. Chen, C. C. Hu, Mater. Int., 2015, 25, 527-544

67. V. D. Patake and C. D. Lokhande, Appl. Surf. Sci., 2008, 254, 2820-2824

68. A. A. Aref and Y. W. Tang, Mater. Sci. Poland., 2014, 32(4), 555-564

69. J. M. Miller, B. Dunn, T. D. Tran and R. W. Pekalaa, J. Electrochem. Soc., 1997, 144(12).
70. J. K. Lee, H. M. Pathan, K. D. Jung and O. S. Joo, J. Power Sources, 2006, 159, 1527-1531

71. A. H. Al-Falahi, IOSR J. Eng., 2013, 3(4), 52-57

72. D. P. Dubal and R. Holze, New J. Chem., 2013, 37, 403-408

73. C. A. Ma, Y. W. Lou, F. M. Zhao, Y. Q. Chu and Y. H. Zhu, Chin. $J$. Nonferrous Met., 2004, 14, 1736

74. E. S. Han, X. P. Zhang, H. Xu and Z. H. Feng, Chin. Battery Ind., 2008, 13, 219

75. V. Vijayabala, N. Senthilkumar, K. Nehru and R. Karvembu, J. Mater Sci. Mater Electron

76. P. Prod'homme, F. Maroun, R. Cortes and P. Allongue, Appl. Phys. Lett. 2008, 93, 171901

77. J. C. Hill, A. T. Landers and J. A. Switzer, Nat. Mater. 2015, 14, 1150-1155.

78. E. B. Svedberg, J. J. Mallett, S. Sayan, A. J. Shapiro, W. F. JrEgelhoff and T. Moffat, Appl. Phys. Lett. 2004, 85, 1353-1355.

79. M. D. Lay and J. L. Stickney, Chem. Soc., 2003, 125, 1352-1355.

80. J. A. Switzer, R. Liu, E. W. Bohannan and F. Ernst, J. Phys. Chem. B, 2002, 106,12369-12372

81. A. Goux, T. Pauporte, T. Yoshida and D. Lincot, Langmuir, 2006, 22, 10545 10553.

82. A.V. Shaikh, R. S. Mane, O. S. Joo, S. H. Han and H. M. Pathan, J. Solid State Electrochem., 2017,21, 2517-2530

83. Y. Zhou and J. A. Switzer, Scr. Mater. 1998, 38, 1731-1738.

84. R. Liu, F. Oba, E. W. Bohannan. F. Ernst and J. A. Switzer, Chem. Mater 2003, 15, 4882-4885.

85. N. K. Mahenderkar. Y. C. Liu, J. A. Koza and J. A. Switzer, ACS Nano, 2014, 8, 9524-9530.

86. P. Poizot, C. J. Hung, M. P. Nikiforov, E. W. Bohannan and J. A. Switzer, Electrochem. Solid-State Lett., 2003, 6, C21-C25.

87. R. Liu, A. A. Vertegel, E. W. Bohannan, T. A. Sorenson and J. A. Switzer, Chem. Mater, 2001, 13, 508-512.

88. S. J. Limmer, E. A. Kulp and J. A. Switzer, Langmuir, 2006, 22, $10535-$ 10539

89. J. A. Switzer, Nanostruct. Mater., 1992, 1, 43-46.

90. R. Liu, E. W. Bohannan, J. A. Switzer, F. Oba and F. Ernst, Appl. Phys. Lett. 2003, 83, 1944-1946.

91. M. Chigane and M. Ishikawa, J. Electrochem. Soc., 2000,147, 2246

92. A. Q. Wang and T. D. Golden, J. Electrochem. Soc., 2003,150, 616

93. M. Chigane and M. Ishikawa, Electrochimica Acta,1997, 42, 1515

94. K. Nakaoka, M. Nakayama, and K. Ogura, J. Electrochem. Soc., 2002 , 149,159

95. M. Izaki and T. Omi, J. Electrochem. Soc., 1996, 143, 53

96. A. Seshadri, N. R. De Tacconi, C. R. Chenthamarakshan, and K. Rajeshwar, Electrochem. Solid-State Lett., 2006, 9, 1

97. Z. S. Iro, C. Subramani and S. S. Dash, Int. J. Electrochem. Sci., 2016, 11, $10628-10643$

98. I. H. Kim, K. B. Kim, J. Electrochem. Soc., 2006, 153, A383-A389.

99. M. Subhramannia, B. K. Balan, B. R. Sathe, I. S. Mulla and V. K. Pillai, J. Phys. Chem. C, 2007, 111(44), 16593.

100. A. Devadas, S. Baranton, T. W. Napporn and C. Coutanceau, J. Power Sources, 2011, 196, 4044.

101. J. P. Zheng, P. J. Cygan and T. R. Jow, J. Electrochem Soc, 1995,142, 2699.

102. C. C. Hu, K. S. Chang, M. C. Lin and Y. T. Wu, Nano. Lett., 2006, 6, 2690.

103. G. Yu, W. Chen, F. Zheng, J. Zhao, Li and Z. Xu, Mater Lett, 2006, 60(20), $2453-6$.

104. T. P. Gujar, W. Y. Kim, I. Puspitasari, K. D. Jung and O. S. Joo, Int. J. Electrochem. Sci., 2007, 2, $666-673$.

105. B. O. Park, C. D. Lokhande, H. S. Park, K. D. Jung and O. S. Joo, J. Power Sources, 2004, 134, 148-152.

106. B. O. Park, C. D. Lokhande, H. S. Park, K. D. Jung and O. S. Joo, J. Mater. Sci, 2004,39, 4313 - 4317.

107. V. D. Patake, C. D. Lokhande and O. S. Joo, Appl. Surf. Sci.,2009, 255, 4192-4196

108. Y. R. Ahn, M. Y. Song, and Y. Kim, Nanotechnology, 2006, 17, 2865-2869.

109. Y. Xie, D. Fu, Mater. Chem. Phys., 2010, 122, 29

110. V. D. Patake, S. M. Pawar, V. R. Shinde, T. P. Gujar and C. D. Lokhande, Curr. Appl. Phys., 2010, 10, 99-103.

111. Y. Z. Zheng, H. Y. Ding and M. L. Zhang, Thin Solid Films, 2008, 516, 
7381-7385.

112. C. C. Hu, M. J. Liu and K. H. Chang, J. Power Sources, 2007, 163, 1126-1131.

113. C. C. Hu and Y. H. Huang, J. Electrochem. Soc., 1999, 146 (7), 2465-2471.

114. C. C. Hu, K. H. Chang, M. C. Lin and Y. T. Wu, Nano Lett. 2006, 6, 12.

115. I. H. Kim, J. H. Kim and K. B. Kima, Electrochem. Solid-State Lett., 2005, 8 (7), A369-A372.

116. I. H. Kim, J. H. Kim, Y. H. Lee and K. B. Kima, J. Electrochem. Soc., 2005, 152 (11) A2170-A2178

117. R. B. Rakhi, Wei Chen, M. N. Hedhili, D. Cha and H. N. Alshareef, $A C S$ Appl. Mater. Int., 2014, 6, 4196-4206.

118. M. Ramani, B. S. Haran, R. E. White and B. N. Popov, J. Electrochem. Soc., 2001, 148, A374.

119. S. Ferro and A. De Battisti, J. Phys. Chem. B, 2002, 106, 2249.

120. Y. Su, F. Wu, L. Bao and Z. Yang, New Carbon Mater., 2007, 22, 53.

121. F. Shi, L. Li, X. Wang, C.Gu and J. Tu, RSC $A d v$., 2014, 4(79), 41910

122. S. C. Pang, M. Anderson and T. W. Chapman, J. Electrochem. Soc., 2000, 147 (2), 444.

123. L. Athouël, F. Moser, R. Dugas, O. Crosnier, D. Bélanger and T. Brousse, J. Phys. Chem. C, 2008, 112, 7270-7277.

124. M. Toupin, T. Brousse and D. Belanger, Chem. Mater, 2002, 14(9), 3946-52.

125. I. Acznik, K. Lota, A. Sierczynska and G. Lota, Int. J. Electrochem. Sci., 2014, 9, 2518

126. M. Toupin, T. Brousse, D. Belanger, Chem. Mate. R, 2004, 16(16), 3184-90.

127. J. K. Chang, M. T. Lee and W. T. Tsai, J. Power Sources, 2007, 166(2), $590-4$.

128. H. Xia, Y. Wang, J.i Lin and L. Lu, Nanoscale Res. Lett., 2012, 1, 7:33.

129. L. Taberna, O. Crosnier, R. Dugas, P. Guillemet, Y. Scudeller, Y. Zhou, F. Favier, D. Bélanger and P. Simon, J. Power Sources, 2007, 173, 633-641.

130. Y. T. Wang, A. H. Lu, H. L. Zhang and W. C. Li, J. Phys. Chem. C, 2011,115, 5413

131. C. Liu, D. Gui and J. Liu, IEEE, 2014, 177, XX.

132. S. Devaraj, G. S. Gabriel, S. R. Gajjela and P. Balaya, Electrochem. SolidState Lett. 2012, 15, A57-A59.

133. B. S. Ming, J. L. Li, F. Y. Kang, G. Y. Pang, Y. K. Zhang, L. Chen, J. Y. Xu and X. D. Wang, J. Power Sources, 2012, 198, 428-431.

134. P. K. Nayak and N. Munichandraiah, Mater. Sci. Eng. B, 2012, 177, 849-854.

135. J. K. Chang and W. T. Tsai, J. Electrochem. Soc., 2005, 152 (10), A2063A2068.

136. S. Hassan, M. Suzuki and A. A. El-Moneim, Am. J. Mater. Sci. 2012, 2(2), 11-14.

137. J. Wei, M. Cheong, N. Nagarajan and I. Zhitomirsky, ECS Transactions, 2007, 3 (37), 1-9

138. D. P. Dubal, D. S. Dhawale, T. P. Gujar and C. D. Lokhande, Appl. Surf. Sci., 2011, 257, 3378-3382.

139. J. Jiang and A. Kucernak, Electrochim. Acta, 2002, 47, 2381-2386.

140. Y. Qiu, P. Xu, B. Guo, Z. Cheng, H. Fan, M. Yang, X. Yang and J. Li, RSC Adv., 2014

141. F. Xiao and Y. Xu, Int. J. Electrochem. Sci., 2012, 7, 7440 - 7450.

142. T. Wanchaem, S. Rattanamai, P. Dulyaseree, W. Jarernboon, and W. Wongwiriyapan, Key Eng. Mater, 2016. 675-676, 273-276.

143. T. Xue, C.L. Xu, D. D. Zhao, X. H. Li and H. L. Li, J. Power Sources, 2007, 164, 953-958.

144. M. T. Lee, J. K. Chang, Y. T. Hsieh, W. T. Tsai and C. K. Lin, J. Solid State Electrochem, 2010, 14, 1697-1703.

145. G. S. Gund, D. P. Dubal, N. R. Chodankar, J. Y. Cho, P. G. Romero, C. Park and C. D. Lokhande, Sci. Rep., 2015, 5, 12454.

146. W. Wei, X. Cui, W. Chen and D. G. Ivey, J. Phys. Chem. C, 2008, 112, 15075-15083.

147. Z. Ye, T. Li, G. Ma, X. Peng and J. Zhao, J. Power Sources, 2017, 351, 5157.

148. S. C. Pang and M. A. Anderson, J. Mater. Res., 2000, 15(10)

149. J. K. Chang, C. H. Huang, M. T. Lee, W. T. Tsai, M. J. Deng and I. W. Sun, Electrochim. Acta, 2009, 54, 3278-3284

150. N. Nagarajan, H. Humadi and I. Zhitomirsky, Electrochim. Acta, 2006, 51,
3039-3045

151. J. K. Chang, C. H. Huang, W. T. Tsai, M. J. Deng, I. W. Sunb and P. Y. Chen, Electrochim. Acta, 2008, 53, 4447-4453

152. T. Shinomiya, V. GuPta and N. Miura, Electrochim. Acta, 2006, 51, 4412-4419

153. J. Duay, S. A. Sherrill, Z. Gui, E. Gillette and S. B. Lee, ASC Nano, 2013, $7(2), 1200-1214$

154. C. C. Hu and C. C. Wang, J. Electrochem. Soc., 2003, 150(8), A1079A1084

155. J. K. Chang and W. T. Tsai, J. Electrochem. Soc., 2003, 150 (10), A1333A1338

156. C. C. Hu and T. W. Tsou, Electrochem. Comm., 2002, 4, 105-109

157. C. C. Hu and T. W. Tsou, Electrochim. Acta, 2002, 47, 3523-3532

158. Rusi and S. R. Majid, Journal. Pone., 2016, 0154566.

159. Rusi and S. R. Majid, Sci. Rep., 2015, 5, 16195

160. H. M. Lee, K. Lee and C. K. Kim, Materials, 2014, 7, 265-274

161. Q. Cheng, J. Ma, H. Zhang, N. Shinya, L. C. Qin and J. Tang, Transact Mater. Res. Soc. Japan, 2010, 35(2) 369-372

162. T. Wanchaem, S. Rattanamai, P. Dulyaseree, P. Khanchaitit and W. Wongwiriyapan, Mater. Today: Proceedings, 2017,4, 6620-6625.

163. Z. Bai, H. Li, M. Li, C. Li and X. Wang, Int. J. hydrogen energy, 2015, 40, 16306-16315.

164. F. J. Liu, J. Power Sources, 2008, 182, 383-388

165. K.W. Nam, C. W. Lee, X. Q. Yang, B. W. Cho, W. S. Yoon and K. B. Kim, J. Power Sources, 2009, 188, 323-331

166. C. Y. Lee, H. M. Tsai, H. J. Chuang, S. Y. Li, P. Lin, and T. Y. Tseng, J. Electrochem. Soc., 2005, 152 (4), A716-A720

167. S. Sahoo, K. K. Naik and C. S. Rout, Nanotechnology, 2015, 26, 455401

168. D.P. Dubal, W.B.Kim and C.D.Lokhande, J. Phys. Chem. Sol., 2012, 73, $18-24$.

169. M.P. Clark, W. Qu and D.G. Ivey, J. Appl. Electrochem.,2017, 47(1), 39-49

170. Y, C. Tsai, W. D. Yang, K. C. Lee and C. M. Huang, Materials, 2016, 9, 246

171. B. Messaoudi, S. Joiret, M. Keddam and H. Takenouti, Electrochim. Acta, 2001, 46(16), 2487-2498

172. P. K. Nayak, N. Munichandraiah, Micropor. Mesopor. Mat., 2011, 143, 206-214.

173. C. Wei, H. Pang, B. Zhang, Q. Lu, S. Liang, F. Gao, Sci. Rep., 2013, 3, 2193-2197.

174. J. X. Zhu, W. H. Shi, N. Xiao, X. H. Rui, H. T. Tan, X. H. Lu, H. H. Hng, J.Ma and Q.Y. Yan, ACS Appl. Mater. Int., 2012, 4, 2769-2774.

175. E. B. Castro, S. G. Real and L. F. D. Pinheiro, Int. J. Hydrogen Energy, 2004, 29, 255.

176. M. S. Wu, Y. A. Huang, J. J. Jow, W. D. Yang, C. Y. Hsieh and H. M. Tsai, Int. J. Hydrogen Energy, 2008, 33, 2921-2926.

177. R. S. Jayashree and P. V. Kamth, J. Appl. Electrochem., 2001, 31, 1315.

178. K. W. Nam, K. H. Kim, E. S. Lee, W. S. Yoon, X. Q. Yang and K. B. Kim, J. Power Sources, 2008, 182, 642.

179. V. Gupta, T. Kawaguchi and N. Miura, Mater. Res. Bull., 2009, 44, 202.

180. H.Y. Wu and H. W. Wang, Int. J. Electrochem. Sci., 2012, 7, $4405-4417$

181. M. S. Wu, Y. A. Huang, C. H. Yang and J. J. Jow, Int. J. Hydrogen Energy, 2007, 32, $4153-4159$

182. R. M. Kore, R. S. Mane, M. Naushad, M. R. Khan and B. J. Lokhande, RSC Adv., 2016, 6, 24478-24483

183. A. D. Jagadale, V. S. Kumbhar, D. S. Dhawale and C. D. Lokhande, J. Electroanal. Chem., 2013, 704, 90-95

184. G. R. Fu, Z. A. Hu, L. J. Xie, X. Q. Jin, Y. L. Xie, Y. X. Wang, Z. Y. Zhang, Y. Y. Yang and H. Y. Wu, Int. J. Electrochem. Sci., 2009, 4, 1052-1062

185. X. Lu and C. Zhao, Nature Comm., 2015, 6, 6616

186. Y. G. Wang and Y. Y. Xia, Electrochim. Acta, 2006, 51, 3223.

187. U. M. Patil, R. R. Salunkhe, K. V. Gurav and C. D. Lokhande, Appl. Surf. Sci., 2008, 255, 2603

188. H. Li, Y. Li, R. Wang and R. Cao, J. Alloys Compd., 2009, 481, 100.

189. Y. Q. Zhang, L. Li, S. J. Shi, Q. Q. Xiong, X. Y. Zhao, X. L. Wang, C. D. Gu and J. P. Tu, J. Power Sources, 2014, 256, 200-205.

190. X. X. Qing, S. Q. Liu, K. L. Huang, K. Z. Lv, Y. P. Yang, Z. G. Lu, D. Fang and X. X. Liang, Electrochim. Acta, 2011, 56, 4985-4991.

191. H. K. Kim, T. Y. Seong, J. H. Lim, W. I. Cho and Y. S. Yoon, J. Power 
Sources, 2001, 102, 167-171.

192. H. Cheng, Z. G. Lu, J. Q. Deng, C. Y. Chung, K. L. Zhang and Y. Y. Li, Nano Res., 2010, 3, 895-901.

193. Z.Y. Xun, C. X. Cai, W. Xing and T. H. Lu, J. Electroanal. Chem., 2003, 545, 19-27.

194. Q. Yang, Z. Y. Lu, Z. Chang, W. Zhu, J. Q. Sun, J. F. Liu, X. M. Sun and X. Duan, RSC Adv, 2012, 2, 1663-1668.

195. V. Srinivasan and J. W. Weidner, J. Power Sources, 2002, 108, 15- 20.

196. Y. Wang, Y. Zhao and C. Xu, J. Solid State Electrochem., 2011, 16, 829.

197. S. G. Kandalkar, H. M. Lee, H. Chae and C. K. Kim, Mater. Res. Bull., 2011, 46, 48-51

198. Z. Xu, A. Younis, D. Chu, Z. Ao, H. Xu and S. Li, J. Nanomaterial, 2014

199. A. D. Jagadale, V. S. Kumbhar, R. N. Bulakhe and C. D. Lokhande, Energy, 2014, 64, 234

200. M. Aghazadeh, M. R. Ganjali and M. G. Maragheh, Int. J. Electrochem. Sci., 2017, 12, $5792-5803$.

201. K. K. Tehare, M. K. Zate, S. T. Navale, S. S. Bhande, S. L. Gaikwad, S. A. Patil, S. K. Gore, M. Naushad, S. M. Alfadul and R. S. Mane, Arab. J. Chem., 2017, 10(4), 515-522.

202. X. H. Xia, J. P. Tu, Y. Q. Zhang, Y. J. Mai, X. L. Wang, C. D. Gu and X. B. Zhao, RSC Adv., 2012, 2, 1835-1841.

203. Y. Shan, L. Gao, Mater. Chem. Phys.,2007, 103, 206-210.

204. V. D. Patake, S. S. Joshi, C. D. Lokhande and O. S. Joo, Mater. Chem. Phys, 2009, 114, 6-9

205. D. P. Dubal, G. S. Gund , C. D. Lokhande and R. Holze, Mater. Res. Bull., 2013, 48, 923-928

206. Y. Li, S. Chang, X. Liu, J. Huang, J. Yin, G. Wang and D. Cao,
Electrochim. Acta, 2012, 85, 393- 398

207. T. S. Ghadge and B. J. Lokhande, J. Mater. Sci., 2016, 51(21), 9879-9888.

208. Q. H. Do, C. C. Zeng, C. Zhang, B. Wang and J. Zheng, Nanotechnology, 2011, 22, 365402

209. M. Sathiya, A. S. Prakash, K. Ramesha, J. M. Tarascon and A. K. Shukla, J. Am. Chem. Soc., 2011, 133, 16291-16299.

210. J. Rajeswari, P. S. Kishore, B. Viswanathan and T. K. Varadarajan, Electrochem. Commun., 2009, 11, 572-575.

211. L. Zheng, Y. Xu, D. Jin and Y. Xie, J. Mater. Chem., 2010, 20, 7135- 7143.

212. A. Ramadoss, G. S. Kim and S. J. Kim, Cryst. Eng. Comm., 2013, 15, $10222-10229$

213. X. H. Xia, Z. Y. Zeng, X. L. Li, Y. Q. Zhang, J. P. Tu, N. C. Fan, H. Zhang and H. J. Fan, Nanoscale, 2013, 5, 6040-6047.

214. S. N. Pusawale, P. . Deshmukh and C. D. Lokhande, Bull. Mater. Sci., 2011, 34, 1179-1183.

215. F. L. Zheng, G. R. Li, Y. N. Ou, Z. L. Wang, C. Y. Su and Y. X. Tong, Chem. Commun., 2010, 46, 5021-5023.

216. X. Zhao, C. Johnston and P. S. Grant, J. Mater. Chem., 2009, 19, 8755 8760 .

217. A. Tamilselvan and S. Balakumar, Ionics, 2016, 22(1), 99-105.

218. H. Y. Lee and J. B, Solid State Chem., 1999,48, 81-84.

219. K. K. Upadhyay, T. Nguyen, T. M. Silva, M. J. Carmezim, and M. F. Montemor, Electrochim. Acta, 2016, 12, 106

220. T. Gujar, V. Shinde, C. Lokhande and S. H. Han, J. Power Sources, 2006, 161, 1479-1485.

221. K. R. Prasad, N. Miura, Electrochem. Commun., 2004, 6, 849-852.

222. K. R. Prasad, K. Koga, N. Miura, Chem. Mater, 2004, 16, 1845-1847. 